\title{
Electrification in Rural Bangladesh Using Solar Home System: Progress, Problems and Prospect
}

\author{
Jaber Al Rashid ${ }^{1 *}$, Ataur Rahman ${ }^{2}$ and Dr. A.K.M Abdul Malek Azad ${ }^{3}$ \\ ${ }^{1}$ Electrical and Electronic Engineering, BRAC University, \\ Dhaka 1212, Bangladesh \\ ${ }^{2}$ Electrical and Electronic Engineering, BRAC University, \\ Dhaka 1212, Bangladesh \\ ${ }^{3}$ Electrical and Electronic Engineering, BRAC University, \\ Dhaka 1212, Bangladesh \\ 1jaberalrashid78@yahoo.com, 2ataur_rahman_shoheb@yahoo.com, \\ 3a.azad@ieee.org
}

\begin{abstract}
Electrification is one of the most crucial factors to ensure economic growth and industrialization in Bangladesh. Being in a developing country, people from various districts of Bangladesh have been experiencing a severe electricity crisis due to the increasing daily demand for power, which outweighs the supply of on-grid electricity. This poor energy situation is evident by the fact that only slightly more than half of the total Bangladeshi population has been able to access on-grid electricity while two-thirds of rural households have been living without. Consequently, the shortage of energy hampers socio-economic development and lowers living standards of people. Since, non-renewable sources such as fossil fuels and natural gas, the primary sources of energy production in Bangladesh, are limited, usage of renewable energy technology (RET) such as solar energy efficiently can satisfy the rising energy demand and in turn improve the existing energy shortage situation. Adopting the Solar Home System (SHS) has enabled access to electricity in households in off-grid rural areas of Bangladesh where the possibility of extending on-grid electricity is less likely in the foreseeable future. This review research paper depicts the progress of SHS in rural areas over the last one and a half decades (1996-2014) and the socio-economic as well as the environmental benefits to SHS households. This paper also presents the prospects of SHS in rural areas of Bangladesh as well as aims to explain some of the challenges which SHS has been experiencing that can hinder significant progress of SHS installations in rural households. Detailed survey results and analysis have been provided in this review paper which indicates noticeable increments in the number of SHSs installed in various rural villages in Bangladesh and the improvements in the livelihoods of SHS adopted households.
\end{abstract}

Keywords: Solar Home System (SHS), Socio-economic, Renewable Energy Technology (RET)

\section{Introduction}

Bangladesh has been facing a severe power crisis for over a decade [1]. Despite the fact that the demand for power has been rising day by day, the production and supply of electricity has been lagging behind, slowing down the sustainable economic growth of the country [2]. Currently, the demand for power is $6000 \mathrm{MW}$ whereas the generation of electricity is only 4300 MW. Hence, the power supply is short by $1700 \mathrm{MW}$, inducing severe disruption in all sectors of life including

* Corresponding Author 
production in fields and factories [3]. Furthermore, the inadequate supply of electricity is clearly observable because only $60 \%$ of the total population in Bangladesh has access to electricity and it has been predicted that this developing country will take further more than a decade to connect everybody with on-grid supply of electricity [4]. Even those who are connected to the grid are facing frequent load shedding due to the deficit in power supply which hampers the living standards of people and economy of the country [5]. Thus, high demand and increasing need for power have created significant challenges to power stations.

The Rural Electrification Board (REB), a state owned utility has got the responsibility for connecting rural areas with national grid [2]. Rural Electrification with on-grid supply by REB has not happened on a large scale. A recent study has been carried out that shows that only $30-35 \%$ of people are connected to the grid [6] which implies that this scenario over the last decade has not changed considerably. Evidently the situation depicts the majority of rural people have been living without any electricity leading to poor way of living that needs to be improved. Considering the geographic locations of many rural areas in Bangladesh, high installation costs to set up new power generation units in these isolated minimally industrial areas, huge investment is required by REB implying that in the near future it is unlikely that many isolated areas will be connected with the national grid [7]. Besides, the presence of 87319 villages in Bangladesh and dispersion of localities transmission and extending grid lines of electricity seems to be highly expensive for rural regions [5]. Thus for rural electrification in off-grid areas, use of solar energy through Solar Home System has been regarded as the feasible form of renewable energy in Bangladesh [2].

In Bangladesh, generation and distribution of power depends largely on primary non-renewable sources such as fossil fuel, natural gas and coal which are very limited in reserve compare to the demand for power to achieve required developments [2, 8]. Around 86\% power stations depend on natural gas for electricity production, while the rest generate power by using coal $(4 \%)$ and $5 \%$ of them rely on fuel oil [9]. However, the quantity of these non-renewable resources are depleting with the passage of time. By the year of 2019-20, the country will face deficiency of its natural gas reserve by 1714 million cubic feet per day (mcfd) to fulfill increasing power demand [10]. Consequently, unlimited and environmentfriendly renewable energy technology (RET), particularly solar energy technology through solar photovoltaic (PV), can meet the unprecedented energy demand by increasing energy accessibility in both on-grid and off-grid areas in Bangladesh which results in an enhancement of energy security due to expansion of this reliable and sustainable renewable energy technology [8]. Therefore, the essence of access to renewable energy such as solar energy, wind energy and biomass is very much important to harness and generate power.

Solar Home System (SHS) is an alternative and viable option which has been available for over a decade and a half for providing supply of electricity in rural and isolated areas in Bangladesh where grid connections are not available [6,7]. Due to the fact that many rural households are unable to get access to grid electricity, in order to accomplish the demand for electricity, adoption of SHS has become popular among the poor rural households with lower income and having lower standards of living because of its affordability and availability of loan system is offered by different organizations [2]. SHS installations and the progress of implementations of SHS programs have been carried out by two different delivery plans. The first model has been enforced by REB, and the second approach is being carried out through a private implementation agency named as Infrastructure Development Company Limited (IDCOL) [2]. This organization has been involved in spreading installations of SHS in rural areas through selling the system to households by applying micro- 
finance scheme, which are carried out by various private agencies. Grameen Shakti (GS) is one such agency that has played a significant role in increasing the number of SHS installations in different rural villages of Bangladesh [11]. According to the report from World Bank (2011), energy access has been increasing at the rate of $3.5 \%$ due to installations of 30000 SHSs on average every month [6]. As a result, the positive impact of SHS on socio-economic aspects has allowed dealing with the energy crisis in rural Bangladesh.

Access to electricity through SHS installations brings positive impact on living standards along with some non-economic benefits such as more leisure time for watching a black-and- white TV in the evening and increased social security due to household lighting. Rural electrification by SHS's installation also ensures improvements in the health and education sector as well as eases poverty by allowing income generation activities [6,12]. Since solar energy through SHS is a clean and environment friendly renewable form of energy, adopting SHS can help to save fossil fuels reserve as well as save cost of energy by replacing kerosene and diesel for lighting purposes causing reduction of environmental hazards[4, 6]. However, the growth of SHS in rural areas has been experiencing some obstacles which are likely to thwart the success of SHS in recent years. The primary obstacle is the high initial cost based on the capacity of SHS during its installation [13]. Rural SHS adopted households also face difficulties regarding the lack of sufficient after sale services, lack of adequate knowledge, lack of sufficient demonstration of the new technology as well as minimal awareness regarding the maintenance of the new technology that are posing obstacles in the advancement of SHS in rural Bangladesh [2, 7].

Despite various problems SHS households may face in the coming years, benefits of using SHSs in off-grid areas seem to increase dissemination of SHSs in the foreseeable future. Considering the remarkable rate at which SHS installations have incremented over last few years, the prospect of SHS expansion is anticipated to be successful and booming in Bangladesh. The Government of Bangladesh (GoB) has made energy policies recently to ensure effective utilization renewable energy resources to meet the demand for power [14]. By the year of 2020, the government has aimed to produce $10 \%$ of total energy through renewable sources [7]. This type of policies promises to result in the exponential growth of SHS ensuring better prospect in various areas in Bangladesh in terms of the size of the SHS market and its economic potential.

The objective of this paper is to reveal the growth of Solar Home System (SHS) in rural Bangladesh along with explaining how SHS users are benefited socially, economically. This paper has been divided into 7 primary sections. Section II provides a brief overview of Solar Home System (SHS) and potential of solar energy in Bangladesh. The growth of SHS and situations of SHSs in rural Bangladesh is presented in Section III with sufficient data and facts. Section IV explains how SHS users have been benefited in terms of socio-economic aspects along with survey results and discuss about the positive impact of SHS on environment. Section V explicates what are the barriers that are likely to slow down the growth of SHS along with survey analysis. Section VI reveals the prospect of SHS in the future with projected data and current energy policies to verify the prediction. Finally, the last section VII gives a conclusion covering the overall scenario of SHS in Bangladesh.

\section{Solar Energy Potential \& Overview on Solar Home SYSTEM (SHS) in Bangladesh}

Considering the ideal geographic location and climate in Bangladesh, the country receives plenty of solar energy that can be exploited and used to generate sufficient electricity in rural areas. Bangladesh has got the optimum location for utilization of 
solar energy because the country is situated between $20.30^{\circ}$ and $26.38^{\circ}$ north latitude, while $88.04^{\circ}$ and $92.44^{\circ}$ east [10]. According to the Bangladeshi location, at this position the availability of sunlight in terms of hours per day has been shown in the graph in Figure 1 [10].

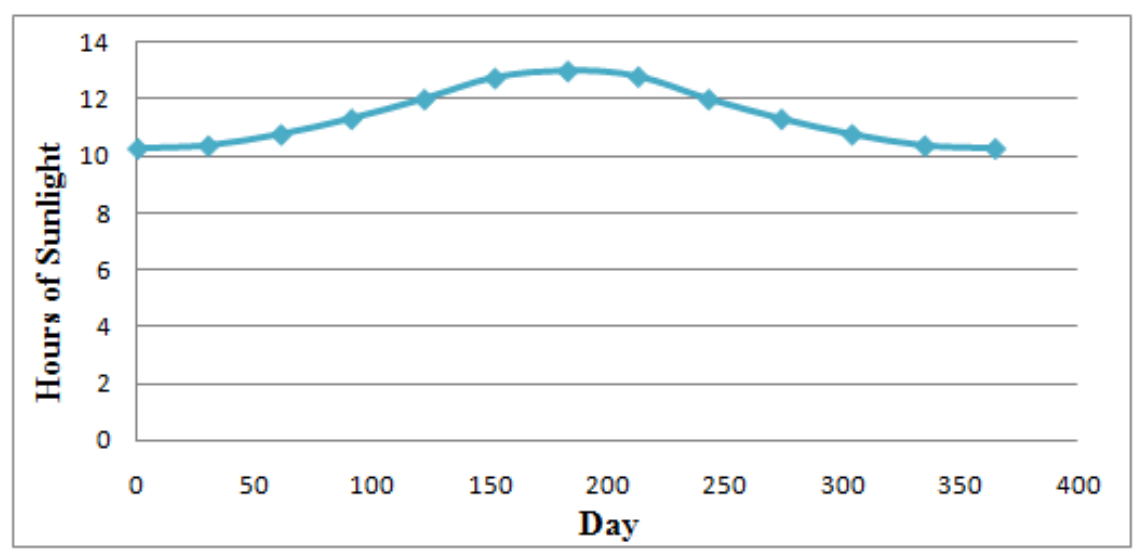

\section{Figure 1. The Amount of Hours of Sunlight in Bangladesh [10]}

The above graph shows that the highest intensity of direct radiation is around 13 $\mathrm{W} / \mathrm{m}^{2}$ and the lowest intensity is just more than $10 \mathrm{~W} / \mathrm{m}^{2}$. Solar energy potential is immense in Bangladesh to generate electricity through Solar Home System (SHS). On average, the daily solar radiation fluctuates between $4 \mathrm{kWh}$ to $6 \mathrm{kWh}$ per square meter [15]. During the month of March-April, the amount of radiation is highest and in the winter season the irradiance from the sun is lowest on the month of DecemberJanuary. The potential of solar energy in Bangladesh is approximated by using GIA based GeoSpatial Toolkit (GsT) and NASA Surface Meteorology and Solar Energy (SSE) solar radiation data [16]. This GeoSpatial Toolkit shows around 94\% surface areas in Bangladesh receive solar radiation. Moreover, the ample availability of solar energy is observable by the data that the annual mean solar radiation is $0.2 \mathrm{~kW} / \mathrm{m}^{2}$. This clearly states that theoretically in every year Bangladesh get around $69751 \mathrm{TWh}$ of solar energy which has been 3000 times more than the amount of on-grid electricity generation in the year of 2006 [16]. Hence, this significant potential of solar energy can be properly utilized through Solar Home System (SHS) to meet the energy demand in off-grid areas.

A Solar Home System (SHS) consists of solar panel, battery storage, charge controller and directly connected DC appliance [17]. In Bangladesh to run a SHS, common DC appliances include: lamps, small fans and televisions as well as others. Solar Photovoltaic (PV) panel has got an array of PV cells. This SHS system presents a technology by which the solar energy is converted into electrical energy. Without the need of using any moving parts, the SHS technology allows households of rural villages to become illuminated through operating DC appliances [4]. While the efficiency of PV panels are more than 15\%, results of carrying out experiment on SHS verify that the overall efficiency of a SHS unit is within the range of 10-12\%, provided that the quality of every component of SHS is good [18]. PV panels that are used in SHSs have got least efficiency, followed by the battery and the load [19]. Figure 2 shows a SHS block diagram using a DC-to-DC converter [19]. 


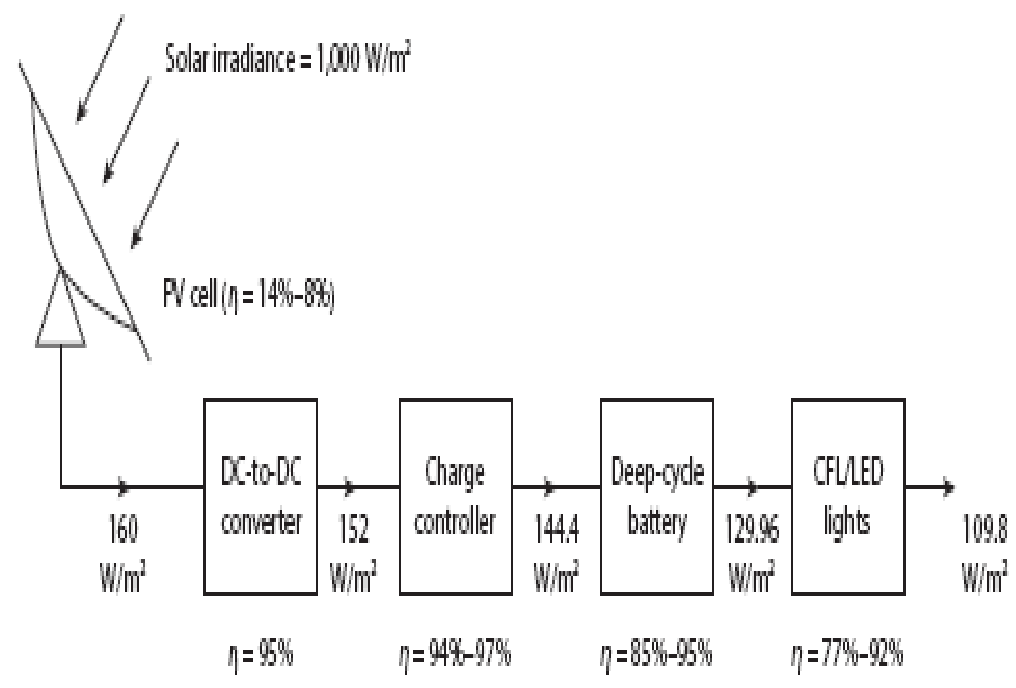

Figure 2. A Typical Block Diagram of SHS [19]

This block diagram shows individual efficiency of every SHS components. The overall efficiency can be calculated by multiplying the efficiency of every component. Charge controllers are locally made and available in the market to satisfy needs of the SHS households by controlling the amount of charging and discharging of batteries and providing power to both DC and AC loads connected with the system [18]. A typical SHS also contains a DC-DC converter, which is a step-up transformer that can be used to alleviate the transmission of power over long distances by decreasing the line loss of the system and increasing the voltage during the transmission. However, a DC-DC converter results in reduction of overall efficiency of the system [18]. Since, the SHS is a complex technology, it is essential for all components of the system to work in a proper synchronization so that optimal performance of the system can be achieved [19]. Furthermore, the quality of SHS components needs to be of high standard. Poor quality PV panels reduce the overall efficiency of the system to around 7-9\% and poor quality components charge controller, battery and lamps (e.g., CFL \& LED) cause frequent replacements. In order to ensure the SHS runs smoothly and has greater longevity, PV panels, which are manufactured internationally and imported to the local markets, need to undergo standard-testing to ensure quality of these panels are ensured through international standards [19]. Other SHS's components such as batteries and charge controllers are produced locally and solar lamps are imported as well as assembled locally by NonGovernmental Organizations (NGOs) and Partner Organizations (POs) such as GRAMEEN SHAKTI, SRIZONY and others. Standard Quality of these components is ascertained by conducting qualification tests at different laboratories in conformity with the technical standard committee of the IDCOL standards [18].

Solar Home Systems (SHSs) of different sizes and capacities can be distinguished in terms of watt-peak (Wp), are available in Bangladesh to produce electricity. Solar PV panels vary in size between $20 \mathrm{Wp}$ to $100 \mathrm{Wp}$. Most common SHS packages that are supplied to rural households by POs are: $30 \mathrm{Wp}, 50 \mathrm{Wp}$ and $75 \mathrm{Wp}$ [16]. Availability of these three packages in the market has been identified by carrying out marketing analysis of the SHS [7]. Table 1 shows how $30 \mathrm{Wp}, 50 \mathrm{Wp}$ and $75 \mathrm{Wp}$ SHS packages differs in terms of number of lighting points, that can be provided by this system [7]. 
Table 1. Packages of Solar Home System [7]

\begin{tabular}{ll}
\hline Package of SHS & Usable items \\
\hline $75 \mathrm{Wp}$ & 6 lamps (8 W each) and 1 B\&W TV \\
$50 \mathrm{Wp}$ & 4 lamps (8 W each) and 1 B\&W TV \\
$30 \mathrm{Wp}$ & 2 lamps (8 W each) and 1 B\&W TV \\
\hline
\end{tabular}

Among these alternative packages, the $50 \mathrm{Wp}$ has got the most popularity among SHS users based on its dominant history. Recently, over the past 1 year, the $30 \mathrm{Wp}$ has been attaining the popularity because of the starting of the usage of LED based lighting system, which are able meet the energy demand of customers by using this smaller capacity system [18]. Three decisional factors have been taken into considerations by customers while choosing an appropriate package of the SHS in rural areas. They are: cost of the package (CP), availability of the package (AP), meeting the demand of the basic household electricity need (HEN). Based on these three attributes, popularity ranking of these SHS packages have been noted to be $42.19 \%$ for $30 \mathrm{Wp}, 29.43 \%$ for $50 \mathrm{Wp}$ and $28.37 \%$ for $75 \mathrm{Wp}$ [7].

Any SHS packages can be bought by paying the total amount of money in advance. Another way to purchase a SHS unit from POs and different NGOs is to pay a down-payment ranging from $12 \%$ to $15 \%$ of the total money of the SHS package and the remaining amount can be paid within 1 year to 3 years through monthly installments [7]. Cost of buying and different loan pricing options by a NGO to purchase any one of these three most commonly available SHS packages are shown in Table 2 [7].

Table 2. Pricing Options of SHSs [7]

\begin{tabular}{|l|l|l|l|l|l|l|}
\hline $\begin{array}{l}\text { Type } \\
\text { of } \\
\text { SHS }\end{array}$ & $\begin{array}{l}\text { Cash } \\
\text { package } \\
\text { price } \\
\text { (US\$) }\end{array}$ & $\begin{array}{l}\text { Down } \\
\text { payment } \\
\text { (US\$) }\end{array}$ & $\begin{array}{l}\text { Loan } \\
\text { amount } \\
\text { (US\$) }\end{array}$ & $\begin{array}{l}36 \text { monthly } \\
\text { installment } \\
\text { amount } \\
\text { (US\$) }\end{array}$ & $\begin{array}{l}\text { 24 monthly } \\
\text { installment } \\
\text { amount } \\
\text { (US\$) }\end{array}$ & $\begin{array}{l}12 \text { monthly } \\
\text { installment } \\
\text { amount } \\
\text { (US\$) }\end{array}$ \\
\hline $75 \mathrm{Wp}$ & 448.05 & 76.17 & 371.88 & 13.43 & 18.60 & 34.09 \\
\hline $50 \mathrm{Wp}$ & 285.71 & 48.57 & 237.14 & 8.57 & 11.86 & 21.74 \\
\hline $30 \mathrm{Wp}$ & 162.34 & 27.60 & 134.74 & 4.87 & 6.74 & 12.35 \\
\hline
\end{tabular}

The tabular data clearly shows that the greater capacity SHS package has got higher costs of installation and more amount of money has to be paid in monthly installments compared to that of the lower capacity SHS packages. These different types of financing schemes help rural households to afford SHS and can experience both social and economic benefits.

\section{Solar Home System Installations \& SHSs Growth}

The Many Government and Non-Governmental Organizations (NGOs) have been contributing to a large extent in the SHS installations and its dissemination. In the year of 1996, an NGO named Grameen Shakti (GS) attempted to use microfinance in order to sell the SHS in off-grid areas of Mymengsingh and Tangail regions so that rural areas could get clean and sustainable solar energy technology through SHS. From 1996 to 1998, GS was able to sell and install only 500 SHSs because of high 
costs of installation and SHS being a new technology for rural Bangladeshi people [20]. After extending their payment period from 1 to 3 years, GS experienced an increase in the rate of SHSs sold during the year 1998 [20]. The government of Bangladesh took the decision of lifting tariff and value added tax on solar PV panels in 1998, which also caused rapid growth of the SHS due to its affordability to rural people [21]. Due to withdrawal of import duty on solar panels, number of SHSs sold by GS had risen up to around 1100 between July 1998 and December 1999 [20].

SHSs installations and its expansion have been occurring substantially in Bangladesh after IDCOL has begun the SHS installations and expansion program in rural areas along with many partner organizations (POs). IDCOL started the program in January 2003 for promoting the growth of SHS in remote rural areas through its Solar Energy Program. This program has been financially supported by World Bank, GTZ, KfW, Asian Development Bank (ADB) and Islamic Development Bank (IDB) [16]. Initially, IDCOL introduced this SHS installations program with the aim to finance 50000 SHSs by the end of June 2008 [16]. However, the target number of SHSs installations had been achieved three years prior to the deadline in September 2005. In order to speed up the SHS financing growth, IDCOL set up a new target of financing 200000 SHSs by the end of the year 2009. This goal was also accomplished by the month of May 2009 [16]. Afterwards, this organization's goal has been to finance 1 million SHSs within the end of the year 2012 [16]. Figure 3 shows financing mechanism of IDCOL and contribution of different NGOs in order to sell the SHS to rural households [7].

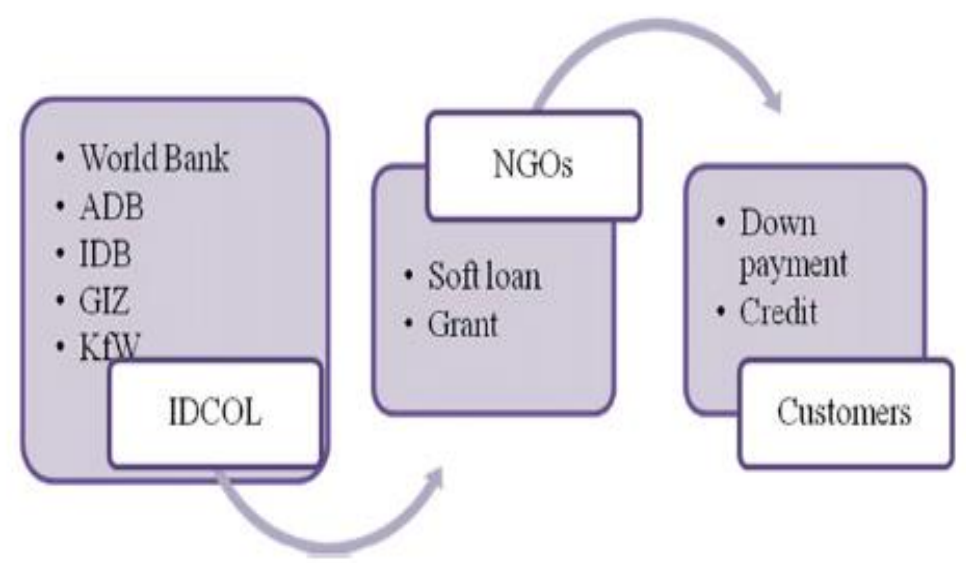

Figure 3. Financing Mechanism of IDCOL [7]

Since, the introduction of the Solar Energy program by IDCOL, till the period of August 2010, a total of 645033 SHSs have already been successfully installed [16]. Several NGOs and POs have played significant role to boost up the rapid growth of SHSs adoptions in rural households by allowing customers to buy SHSs on credit. The graph below in Figure 4 shows contributions of 23 POs regarding the number of SHSs installations till August 2010 [16]. 


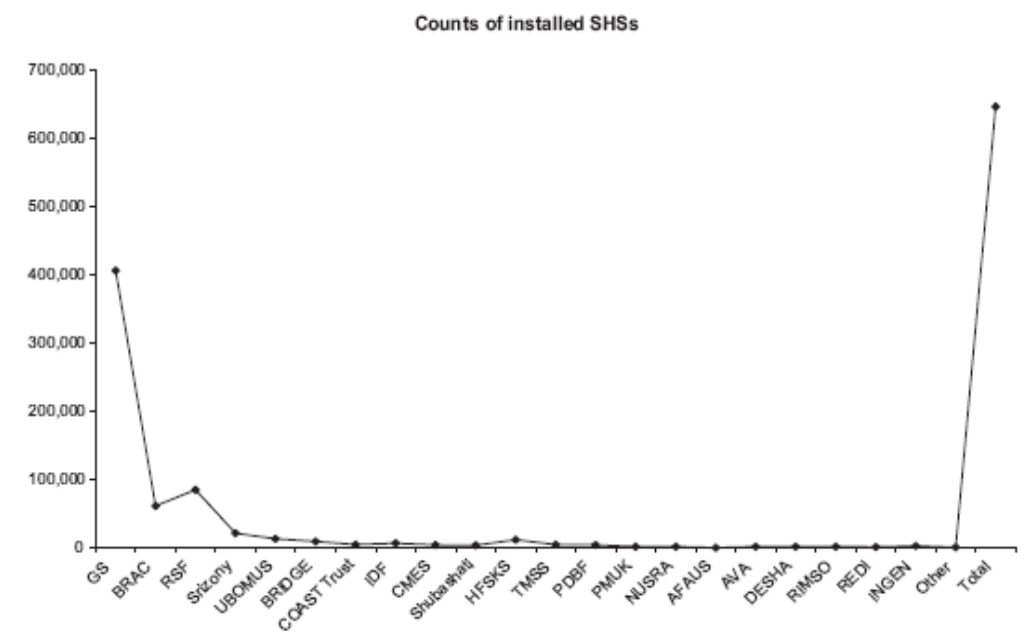

Figure 4. Number of SHSs Installed by 23 POs of IDCOL upto August 2010 [16]

The graph clearly indicates that Grameen Shakti (GS) has been able to sell highest number SHSs compare to other POs of IDCOL. After 2010, SHSs installations have fulfilled the rising demand for power significantly. Figure 5 provides the numerical data of how the total number of SHSs (645033) adoptions up to August 2010 has been distributed among six divisions in Bangladesh [16].

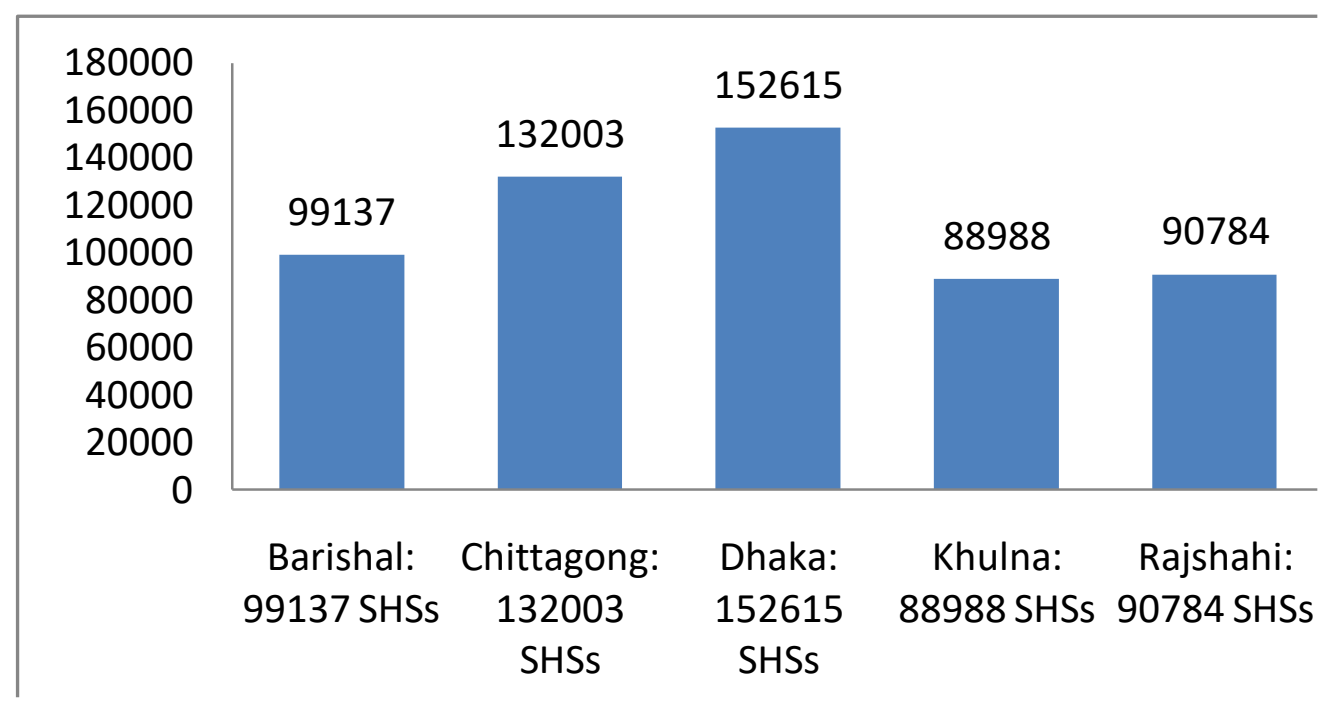

\section{Figure 5. Division Wise SHSs Installed by IDCOL upto August 2010 [16]}

According to a report from World Bank (2011), on an average 30000 SHSs are installed in every month in rural Bangladesh, enabling an increment in the access to electricity upto 3.5\% [6]. The growth of the SHS adoption and number of SHSs installations have raised rapidly and noticeably with passage of time. Numbers of SHSs installations by various NGOs using the support of IDCOL have reached a total of 1320965 SHSs, with a capacity of nearly more than 36.5 MW by the year of February 2012 [22]. Thus it is observed that between August 2010 and February 2012 , the growth of SHSs boosted with a sharp multiple of more than doubled from 645033 to 1320965 numbers of SHSs installations. The pie-chart below in Figure 6 presents distributions of the total numbers of SHSs installations among all 6 divisions in Bangladesh upto February 2012 [10]. 


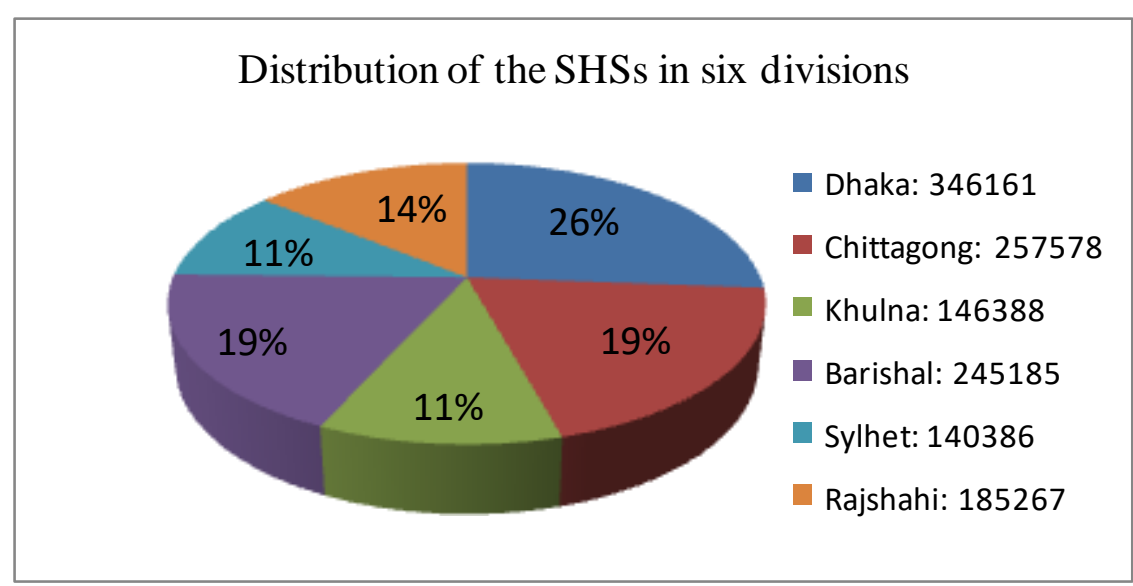

\section{Figure 6. Distributions of SHSs in Six Divisions in Bangladesh upto February 2012 [10]}

By contrasting Figures $5 \& 6$, the extent to which the progress of installing SHSs has increased from midway of the year 2010 to 2012 can be observed. During this period in every division, numbers of SHSs installed have been almost doubled. Furthermore, different POs and NGOs have worked selling SHSs to rural households and the Figure 7 below shows the quantity of SHSs sales which have been set up by some of the organizations till the year 2012 [23].

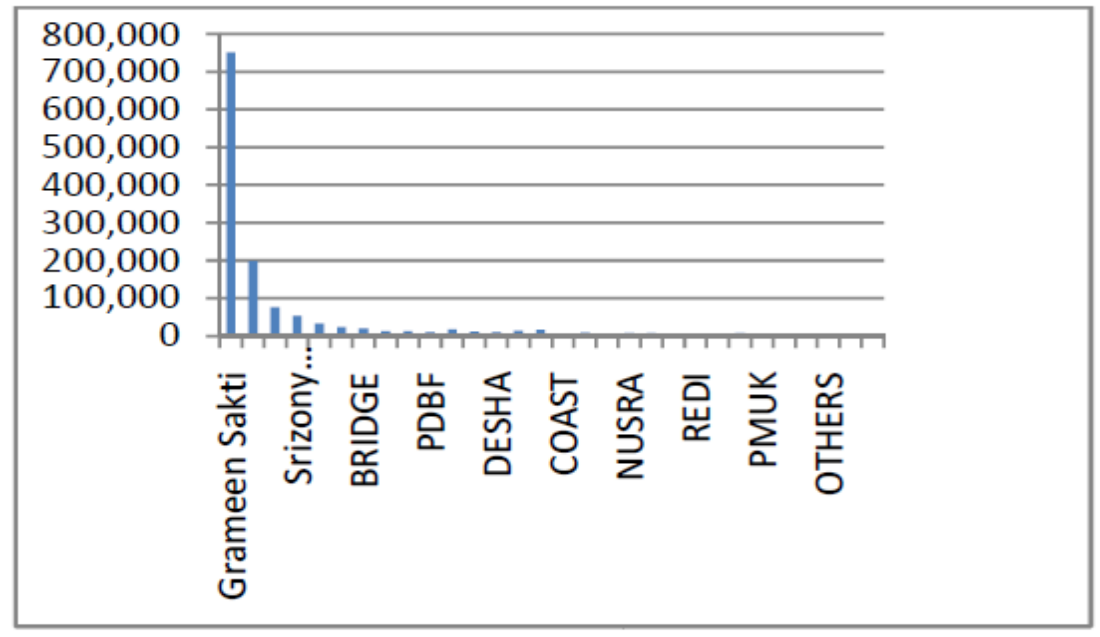

Figure 7. SHS's Installations upto February 2012 [23]

Expansion of SHSs installations can be determined by comparing the data shown in Figures 4 and 7. The data provided in these figures indicate that between August 2010 and February 2012, the SHS installations by Grameen Shakti have increased considerably from 400000 to more than 700000. Other POs such as Srizony, BRAC as well as others had also played a significant role in gradual enhancement of SHS installations during this period. Table 3 below shows the exact amount of SHSs installations in rural areas by some other partner organizations upto February 2012 [10]. Comparing this tabular data with the graphical data as shown in Figure 5, it is possible to explain how the expansions of SHS have taken place in rural Bangladesh. 
Table 3. SHS's Installation upto February 2012 [10]

\begin{tabular}{|c|c|}
\hline Partner Organizations & Number of SHS's Installed \\
\hline RSF & 199209 \\
\hline UBOMUS & 23651 \\
\hline $\begin{array}{c}\text { Integrated Development } \\
\text { Foundation( IDF) }\end{array}$ & 12618 \\
\hline AVA & 10564 \\
\hline CMES & 5543 \\
\hline
\end{tabular}

Analyzing the data in Table 3 with the graphical representation of the data in Figure 4, it clearly depicts that the adoption of SHSs by rural households had surged dramatically within a period of one and half years. The graph shows in mid 2010, RSF installed around 100000 SHSs and till the start of 2012 the number has shot up to 199209. Similarly, other POs like UBOMUS, AVA, CMES and IDF had very few installations of SHSs in 2010 but their vital contributions in promoting the dissemination of SHS in rural areas has been ascertained in terms of noticeable increase in sales of SHSs till the year of 2012. At this rate, the growth of SHS has resulted setting up of a total of 19328957 SHSs by IDCOL through its POs all over the Bangladesh upto January 2013 [24]. Between February 2012 and January 2013, IDCOL has been capable to diffuse usage of SHSs, taking the help of 30 POs by establishing 20000 more SHSs in rural households every month and adding up 2.0 MW to national electricity generation [6]. Consequently, IDCOL has supplied electricity to 200000 people due to installations of 50000 SHSs every month by the year of 2013 [6]. At the end of the year 2013, the total number of sales of SHSs had soared to more than 2.7 million [25]. Figure 8 represents this remarkable exponential progress of SHSs adoption which had continued from 2003 to 2013. The figure 8 clearly showcases that the total number of units SHSs installed by the POs in every individual years with the support from IDCOL has increased exponentially from only 20000 (20 SHSs units in thousands) SHSs to 490000 (49 SHSs units in thousands) between 2003 and 2009. At the end of 2010, the number of SHSs installations had been almost doubled to 800000 SHSs units, followed by gradual progress of SHS installations for the next three years reaching 12500000 units and 17000000 at the end of year 2011 and 2012 respectively which resulted due to the adoption of SHSs by rural households. By the beginning of the year 2014, the total number of SHSs installations had been attained up to 3 million bringing benefits to nearly 15 million rural people [25]. 


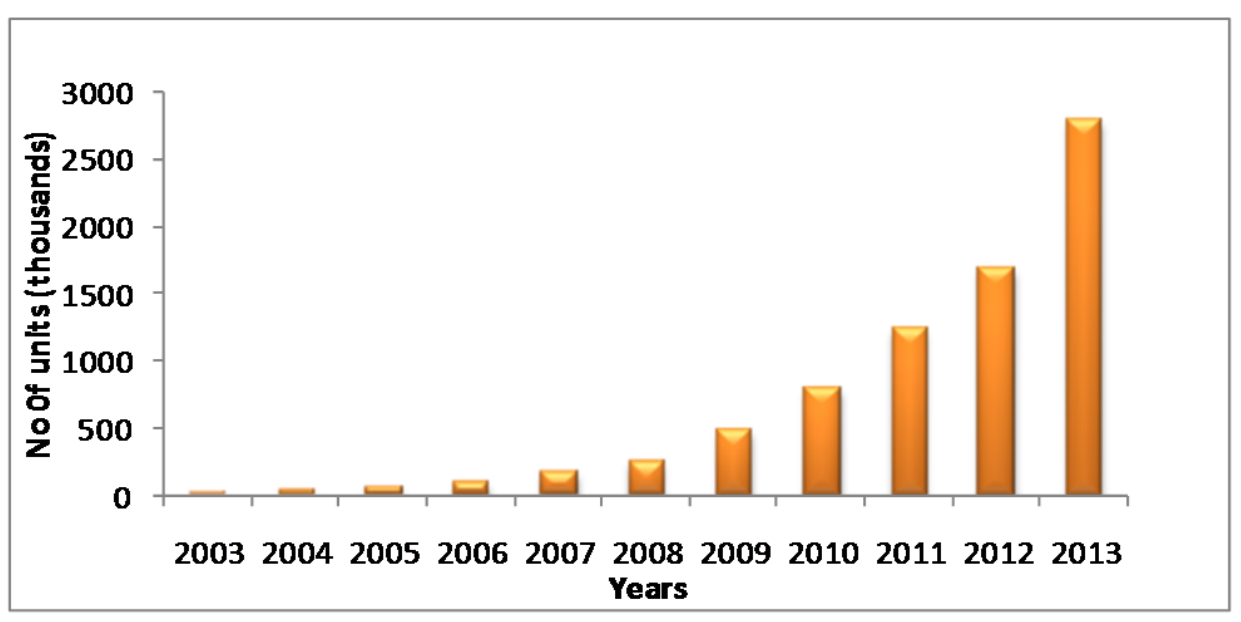

Figure 8. Accelerated Growth in Bangladesh's SHS Installations [25]

Since the start of the SHS program in 2003, the number of registered POs has reached close to 49. Distributions of SHSs installations by different POs until March 2014 are shown below in Figure 9 [25].

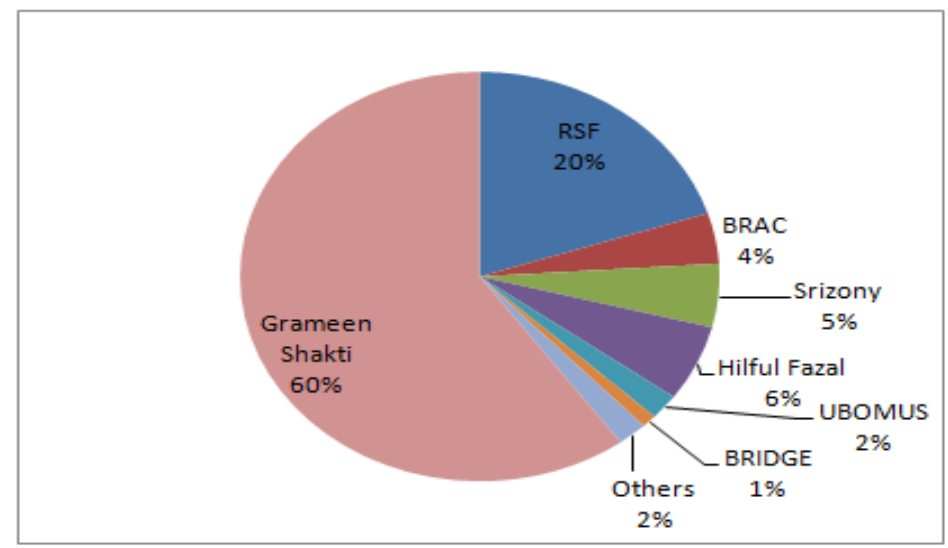

Figure 9. Distributions of SHSs Installations by Partner Organization upto March 2014 [25]

Grameen Shakti has pioneered in SHSs diffusion as it has largest market share which is $60 \%$ of all SHSs installations till March 2014. According to Figure 9, RSF has been the second largest PO due to its contribution in $40 \%$ of all SHSs installations until March 2014 [25].

Bangladesh Power Development Board (BPDB) and Rural Electrification Board have also distributed SHSs to the people living in off-grid areas. BPDB has carried out a remarkable Solar PV electrification project in Chittagong hill tracks Region which has come out as the most feasible and appropriate technological approach in rural areas [2]. In the Juraichari sub-district, a total of 300 SHSs (ranging 75-129W) with a capacity of $36 \mathrm{KW}$ had been installed by BPDP by the start of 2005 [16]. The Rural Electrification and Renewable Energy Development Project (REREDP) are considered to be the largest renewable energy project in Bangladesh [7]. The objective of this project is to render SHSs in rural Bangladesh. Within a period of nine years (2003-2011), 1 million SHSs have already been installed in accordance with the model of RERDP [26]. 
The Government of Bangladesh has taken a renewable energy policy for the purpose of harnessing, distributing and improving the growth of the usage of renewable energy. Ministry of Power, Energy, and Mineral resources (MPEMR) improved and finalized a renewable energy policy (REP) in December 2008 [27]. According to the REP 2008, some of the policies has to be implemented which include: a) facilitating the use of renewable energy at every level of energy usage, b) promoting appropriate, efficient and environment friendly use of renewable energy and c) encouraging development of local energy in the field of renewable energy [27]. In the REP 2008, the Bangladeshi government took the decision to launch an independent unit, named as the Sustainable Energy Development Authority (SEDA) instead of the Renewable Energy Development Authority (REDA) for hastening the use of renewable energy to generate power [28]. The objective of the REP 2008 is to ensure faster growth of renewable energy technology such as solar energy technology through the usage of SHS. Therefore, this renewable policy has exemplified roles of SEDA, which involve supporting capacity building, technological development and adequate market development to raise the growth of electricity generation from RETs [16]. Formulation of favorable Tariff policy for renewable energy such as solar energy and others as well as development of feasible financing system by the government also play a vital role in favor of the progress of SHSs in rural Bangladesh. The government can establish viable financial system to promote PV diffusion, provide temporary tax exemptions for buying PV equipments and help in the reduction of energy price distortion [16]. The rapid ongoing progress of renewable energy technology including SHSs has also been alleviated by formulating the REP 2008. In order to promote the expansion of SHS, the government has proposed some financial incentives in the REP 2008 [16, 27]. Two very important incentives that help to surge the progress of SHSs are: 1) Renewable energy components such as PV panels, battery, charge controller and other related energy equipments will be exempted from 15\% Value Added Tax (VAT), 2). An incentive tariff may be considered for power generation from the usage of renewable energy sources and the amount can be $10 \%$ more than the highest buying price of electricity by the utility from private generators $[16,27]$.

\section{Positive Impacts of SHSs on Rural Households \& to the Environment in Bangladesh}

SHS-adopter rural households have experienced immense benefits due to installations of Solar Home Systems (SHSs) compare to that of those non-adopter households. SHSs have positive socio-economic impacts on the lives of rural households. SHSs help to preserve fossil fuel and to ease the reduction of poverty by providing income generation opportunities [6]. Access to electricity through the SHS can upgrade living standards of people in rural areas as well as it allows better facilities on education, recreation and communication for rural people [4]. Several Surveys were conducted in different rural areas by different organizations and researchers to find out how quality of lives of rural households has been improved because of installing SHSs in Bangladesh.

\subsection{Socio-Economic Benefits of SHSs}

Adopters of SHSs in rural areas receive benefits instantaneously by getting the opportunity to access electricity through household lighting, which is the primary use of electricity [29]. Since, in rural households, installing SHS can provide ample light after dark that helps the children on their education by providing extended-study hours for these school going children [18]. Moreover, the SHS enables the rural to spend more relaxation time by acquiring important knowledge and having access to useful socially desirable 
information happening around them through the electronic media (e.g., black-and-white $\mathrm{TV}$, and radio) $[29,18]$. A large household survey was conducted among SHS adopters and non-adopters in 128 villages [18]. A total of 1600 SHSs installed households in SHSs supplied villages and 400 SHSs non-adopter households from both SHSs villages and nonSHSs villages were surveyed to analyze various impacts of SHSs, direct or indirect, on the adopter-households [18]. Table 4 shows the survey data regarding the influence of SHSs on children's education for both SHSs and non-SHSs households [18].

Table 4. Educational Outcome by SHS Adoption for Children of Aged 518 years [18]

\begin{tabular}{|c|c|c|c|c|c|}
\hline $\begin{array}{l}\text { Education } \\
\text { Outcome }\end{array}$ & $\begin{array}{l}\text { Gender of } \\
\text { Children }\end{array}$ & $\begin{array}{c}\text { SHSs } \\
\text { Households } \\
\text { (HHSs) }\end{array}$ & $\begin{array}{c}\text { Non-SHS } \\
\text { HHs from } \\
\text { non-SHS } \\
\text { villages }\end{array}$ & $\begin{array}{c}\text { Non-SHS } \\
\text { HHs from } \\
\text { SHS } \\
\text { villages }\end{array}$ & $\begin{array}{c}\text { All non- } \\
\text { SHS } \\
\text { HHs }\end{array}$ \\
\hline $\begin{array}{c}\text { Evening study } \\
\text { duration } \\
\text { (minutes/day) }\end{array}$ & Boys & 131.3 & 120.3 & 118.5 & 120.0 \\
\cline { 2 - 6 } & Girls & 127.3 & 114.9 & 115.6 & 115.0 \\
\hline $\begin{array}{c}\text { School } \\
\text { attendance } \\
(\%)\end{array}$ & Boys & 77.5 & 72.6 & 75.9 & 73.2 \\
\hline $\begin{array}{c}\text { Grades } \\
\text { completed } \\
\text { (years) }\end{array}$ & Goys & 81.2 & 76.5 & 80.0 & 77.0 \\
\cline { 2 - 6 } & Girls & 3.8 & 3.1 & 3.7 & 3.2 \\
\hline
\end{tabular}

Data in Table 4 shows that both boys and girls of SHSs households, on an average study 10-12 minutes more in the evening than those who study without solar lights. Besides, the above table also presents the percentage of school attendance and the completion of higher levels of education is also greater for children of SHS adopter-households compared to that of non-adopters [18]. Thus, it can be evaluated that the availability of SHS helps children to educate themselves by studying longer time period in the evening as well as due to extended study hours, the year of schooling completed has been found to be higher for children with SHS than those without it.

Access to electricity through installations of the SHS can provide significant health benefits indirectly to SHS adopted households. Through the selection of the environment friendly SHS as the mode of rural electrification may likely reduce the frequent occurrence of illness, especially respiratory diseases or related illness and gastrointestinal diseases [29]. A typical SHS unit can allows its users who can afford to buy and run a small or medium sized black-and-white TV. Unlike non-SHS users, households with SHS can get the opportunity to buy a TV and operate it by the help of electricity generated through the assistance of SHS [29]. These well-off SHS users are encouraged to buy a TV and they can watch various types of educational and health related programs that are usually telecasted in various TV channels, allowing the SHS viewers to gain more useful information and news about health-related issues [29]. Hence, installation of the SHS and watching health related programs can help both male and female households to acquire more information regarding prevention and cure of various types of diseases than SHS non-adopters. Subsequently, knowing this useful information about health safety and maintenance of health form various diseases allows the SHS users to minimize incidences of illness by increasing the health awareness and following the hygiene practices among the SHS households. A survey was conducted in 128 villages among 1600 SHSs households. Figures $10 \& 11$ presents survey results regarding incidences of various illness among 
children and adults of SHSs users [18]. The survey results in figure 10 shows that the incidence of illness for children in SHS adopted households under the age of 15 have been lowered by $10 \%$ due to having the opportunity to watch TV unlike those children SHS non-adopted households who have been unable to watch TV in order to get awareness on how to prevent and cure various health related illness. Furthermore, the survey results have also found lower incidence of GI illness (6\%) for children in SHS adopted households with TV than that of for boys and girls (10\%) without TV ownership in non- SHS households.

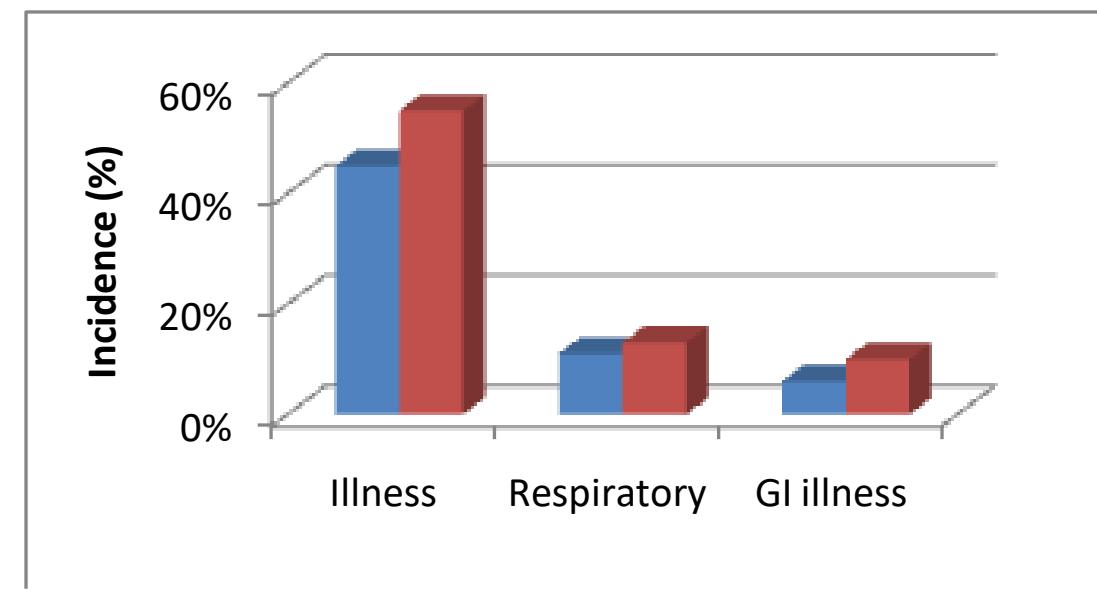

\section{Figure 10. Incidence of Illness among Children (age $<15)$ in SHS Households by Availability of TV [18]}

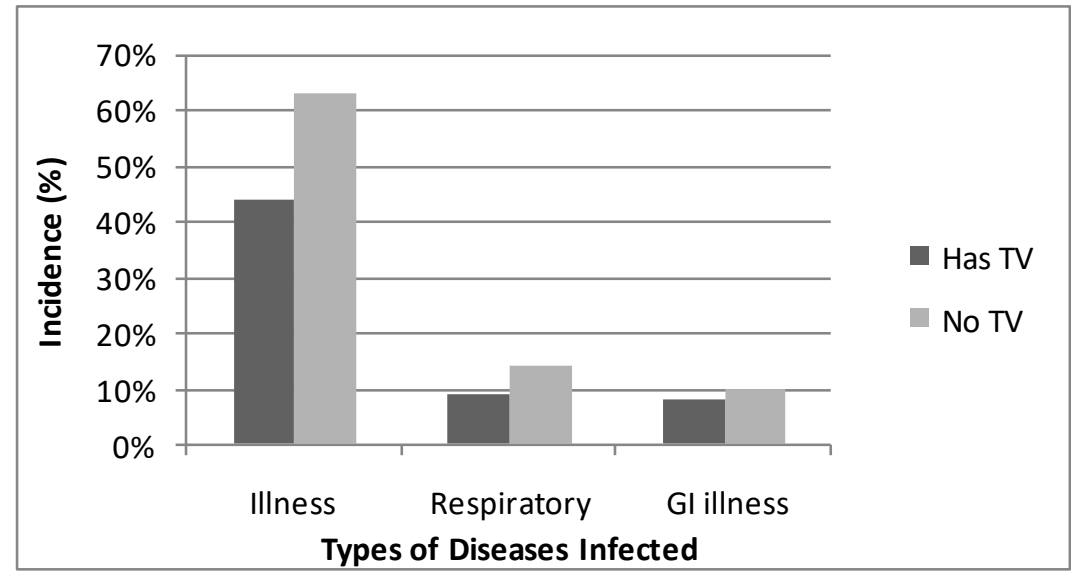

\section{Figure 11. Incidence of IIIness among Adults (age $>15)$ in SHS Households [18]}

Both the figures $10 \& 11$ depicts clearly that households with SHSs, chances of being infected by some particular diseases are very low because of availability of TV that helps them to attain knowledge on how to cure and prevent from being infected by different types of diseases. The data in Figures 10 and 11 indicate that both children under the age of 15 and adults living in the installed SHS houses with the opportunity to watch TV have got lower percentages of being infected by diseases than those without getting the chance to watch TV due to absence of electricity. The results also show that for both boys and girls in SHSs households with TV ownership, the incidence of respiratory diseases decreases by $2 \%$. The numerical survey data in figure 11 clearly resembles that the incidence of respiratory diseases, GI illness and other various types of health related illness infected to adults were only $44 \%, 9 \%$ and $8 \%$ respectively in SHS adopted households 
with the opportunity to watch TV, which is significantly lower than that of incidence of these same type of disease caused to adults in non -SHS adopted households where adults lack the opportunity to watch TV for obtaining knowledge on how to prevent and cure these types of diseases. It is observed that the SHS with the required capacity to run a black-and-white TV may help indirectly to reduce prevalence of diseases through learning of prevention procedures of epidemic diseases from watching various health related programs on TV. Moreover, by watching TV programs also allow women to acquire knowledge of reproductive health issues that can inspire them on taking care of contraception and recent fertility issues [30]. A survey was conducted in 2012 by Bangladesh Institute of Development Studies (BIDS) and the World Bank (BIDS/World Bank 2012) [29]. The study has found that recent fertility for women is improved and the contraceptive prevalence is higher for among married women of adopter-households than those of non-adopter households [29]. Thus, by staying awake to watch maternal and child related health programs on TV helps raising awareness and concern about maternal and child health [18].

The SHS can also help to alleviate the poverty reduction by providing income generation activities. Adoption of the SHS seems to be responsible for the increase in household income, assets and expenditure [29]. Solar power contributes to increment per capita expenditure from $4 \%$ to $5 \%$, per capita income from $9 \%$ to $12 \%$ and durable home goods from $23 \%$ to $27 \%$ [29]. The SHS's installation on the rooftop of every rural house enables households to recharge their mobile phones without going to shops where a certain amount of money is usually charged by the shopkeepers. Therefore, SHS users can save the amount of money they need to spend for charging their mobile phones in different phone charging business shops. Consequently, a SHS unit can influence the people to carry out some income generating activities that can surely improve their existing economic situations. Income generating activities may also involve as taking a fixed amount of money in the form of rent for electricity bill from the rural people who are willing to charge their mobile phones inside the SHS adopted houses. Increase in income through electrification by SHS was also evident in a survey that was conducted among 100 randomly chosen rural households in Panchua village of Gazipur District. This survey revealed that the monthly income of many SHS adopted villagers raised by BDT 1000 after the installation of SHS which enabled them to conduct their businesses for late hours after the evening [31]. SHS users do no longer need to spend money for buying kerosene and lamps for lighting after dusk. Therefore, SHS-adopters can save considerable amount of money in this sector and thus the economic situation can be improved slightly unlike SHS non-adopters. SHS can help many women to create their own businesses as clothes designer and run small businesses even at night to generate their additional income by extending their working hours after dusk, allowing to become self-independent and develop their entrepreneurial skills through carrying out various other kinds of business generating activities including weaving, farming and poultry [31]. SHS adopters can also carry out business activities by communicating with others using charged mobile phones and conduct business activities in the late evening by running a social TV hall where all non SHS users can come and watch TV for entertainment purposes and they have to pay a certain amount of money for watching movies and drama on TV [6]. According to Bangladesh Bureau of Statistics, the results of Household Income and Expenditure Survey, 2010 showed that the average income of SHS non-adopters was BDT 7866 whereas the income increased up to BDT 9648 for SHS adopters. The extended survey also stated that because of SHS installations their income has boosted such that around 54.5\% households' monthly income was around BDT $8000-12000$, but this number was only $42.2 \%$ before installing SHSs in houses. With the improvement in the economic situation of the rural families who have adopted SHS and can do businesses by the electricity, their poverty reduction has also happened noticeably along with the improvement in their standards of living. A study was conducted regarding the financial feasibility of using SHSs, showing 
an increase in monthly income of BDT 800-1000 ensuing to an increase of approximately $25 \%-33 \%$ income over the existing income as well as the use mobile phones has also increased in four cases [17].

Overall, the socio-economic benefits of SHSs and the quantity of SHSs installed by rural households appear to be linked with each other. Rural households tend to consider benefits of the SHS while purchasing a typical SHS unit. A household survey and interviews were conducted with owners of SHS in villages of konabari [4]. Figure 12 shows clearly the survey data describing reasons for purchasing SHS in rural households [4].

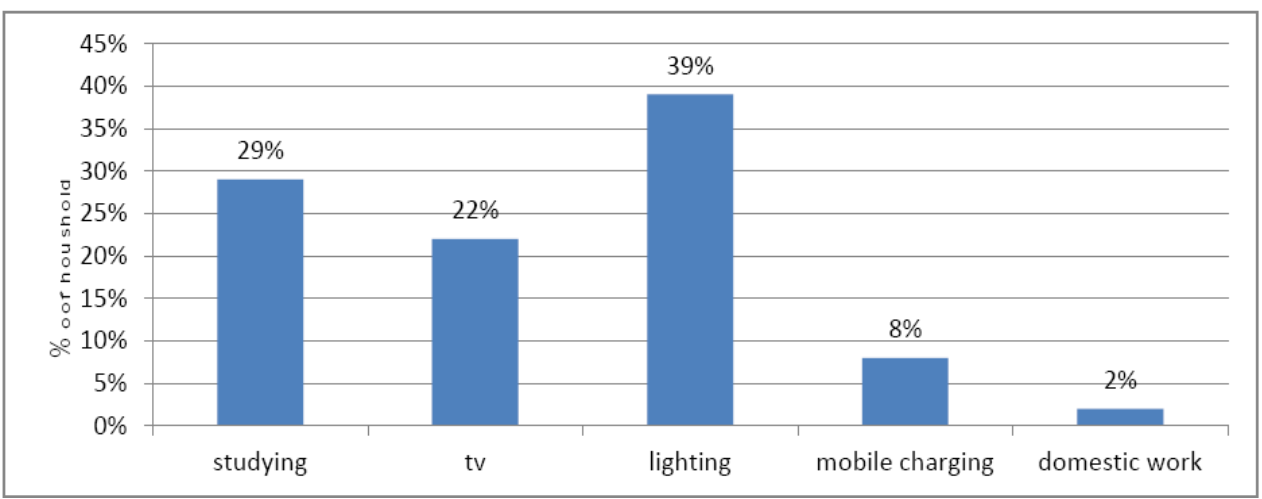

Figure 12. Respondents Decide To Purchase a SHS [4]

The Figure 12 shows that the choice of SHS installations by rural households depends mostly for getting the improved quality of lighting (39\%) inside the house and getting the opportunity to study for a longer time period due to ample lighting (29\%) [4]. The survey results also shows that exactly $22 \%$ owners of rural households prefer to install SHS in rural houses in order to run a black and white TV. While a total of $4 \%$ rural households installed SHS for charging their mobile phones and a merely $2 \%$ households have used SHS for conducting domestic works. It can be evaluated that the rural people have been motivated to improve their lifestyles which influence installation of the SHS.

\subsection{Environmental Benefits}

Since, the solar energy is a clean and non-renewable forms of energy source, the SHS is an environment friendly and do not create any environmental degradation. Kerosene-based lighting plays a vital role in global warming and poses severe health and safety hazards [29]. Furthermore, burning of kerosene for household lighting has serious long-term effect on global warming because it is approximated that the use of kerosene lamps emit globally 244 million of tons of carbon dioxide gas every year [29]. Access to electricity in rural areas using the SHS allows significant reduction of kerosene usage for lighting lamps. Installations of SHSs in rural households mean by decreasing the emission of carbon dioxide gas $(\mathrm{CO} 2)$ to the atmosphere. Even the contribution of SHS is also involved in replacing the candles for lighting as well as prevent women and children from the burden of collecting firewood for lighting fire after dusk, and thus making the environment better by quitting the act of deforestation, loss of biodiversity and degrading forests as SHS rural households no longer need firewood for following primitive way of lighting [31]. Since the carbon dioxide gas is responsible for global warming, slowing emissions of this gas can minimize deteriorating the environment. By using the BIDS/World Bank 2012 survey data, table 5 shows reduction in $\mathrm{CO} 2$ emission due to installation of SHS [29]. 


\section{Table 5. Reduction in CO2 Emissions from kerosene replacement due to SHS Adoption [29]}

\begin{tabular}{|c|c|c|c|c|c|c|}
\hline \multirow[b]{2}{*}{ Factor } & \multicolumn{5}{|c|}{$\begin{array}{l}\text { Carbon dioxide }(\mathrm{CO} 2) \text { emission, by income } \\
\text { quintile }\end{array}$} & \multirow[b]{2}{*}{$\begin{array}{c}\mathrm{CO} 2 \\
\text { emissions } \\
\text { for all } \\
\text { households }\end{array}$} \\
\hline & $1^{\mathrm{st}}$ & $2^{\text {nd }}$ & $3^{\text {rd }}$ & $4^{\text {th }}$ & $5^{\text {th }}$ & \\
\hline $\begin{array}{l}\text { Non-SHS } \\
\text { household }\end{array}$ & 6.2 & 6.2 & 6.8 & 7.5 & 8.3 & 6.9 \\
\hline $\begin{array}{c}\text { SHS } \\
\text { households }\end{array}$ & 1.3 & 1.3 & 1.3 & 1.5 & 1.6 & 1.4 \\
\hline $\begin{array}{l}\text { Difference } \\
\text { in } \\
\text { emissions }\end{array}$ & 5.0 & 4.9 & 5.5 & 6.0 & 6.7 & 5.5 \\
\hline
\end{tabular}

Data in Table 5 explains that the emissions of the carbon dioxide gas by Non-SHS households' members are greater than that of SHS households as well as the difference in carbon dioxide emanations increases as the household income increments. Thus, it implies that with an increase in income, the non-SHS users consume more kerosene compare to SHS users for lighting purposes and as a consequence greater quantity of $\mathrm{CO} 2$ gas is given out to the atmosphere. Due to the SHS adoption, the total decrease in the amount of the carbon dioxide emission is $5.5 \mathrm{~kg}$ per household, causing a substantial minimization of about 160 million $\mathrm{kg}$ of $\mathrm{CO} 2$ emission in each year for all the existing SHS adoptedhouseholds in Bangladesh [29]. Adopting SHSs in rural houses brings positive impact to the environment by reducing the emission of greenhouse gases to the atmosphere. The fact that the SHS is environment friendly is also evident because the users of SHS are hardly responsible for global warming as their average consumption of kerosene (a source of $\mathrm{CO} 2$ gas emission) per month is 3.5 times less than the non-SHS households [18].

Furthermore, replacing the usage of kerosene for adopting a SHS unit provides better indoor quality [6]. Kerosene lamps are one of the major sources of Household Air Pollution (HAP) because burning of kerosene emits black carbon which is responsible for causing respiratory problems [29]. On the other hand, the SHS does not contribute to any indoor pollution hence allowing SHS users to stay healthy. Rural electrification through SHS also plays noticeable role in climate protection which is also evident from the fact that significant amount of fossil fuel usages especially kerosene is reduced by every SHShousehold rather non-SHS adopters resulting bringing down the overall usages of kerosene to more than 92 million liters in every year because of SHS installations throughout the rural Bangladesh $[32,33]$. Thus, rural electrification using SHS do not develop any soot or any noxious odors unlike kerosene, ensuring 100 times better quality lighting without providing any adverse effects to the environment [32].

\section{Barriers of SHS \& Problems Affecting Expansion of SHS in Bangladesh}

Although the progress of SHSs has been substantial over the years, some existing barriers and problems impede the significant dissemination of SHSs in rural Bangladesh. One of the most important economic \& financing barriers is the high initial cost of installing a typical SHSs unit [16]. A group of wealthier rural people with sufficient land and other sources of income can afford high installation costs required to establish SHSs in their houses compared to that of some lower income poorer people who have got difficulty 
to pay the high down payment price [6]. Besides, the existing financing mechanism that is followed by few POs and other respective organizations appears to be inappropriate and affordable for very poor SHS non-adopters. Nevertheless, the existing credit system some fewer rural villages is yet inaccessible along with high loan financing mechanism act as financial obstacles for these poorer non-SHS users in fewer off-grid areas to afford SHS in their households [16]. Hence, the prompt diffusion of SHSs in all over the rural Bangladesh acts as a hindrance to a certain extent as considerable amount of very low income groups of non-SHS users still are unable to implement SHS in their households. On some cases, there are very few existing Market barriers, Informational barriers and Policy barriers affecting the booming of SHS in rural areas [16]. Market barriers are included as follows: (a) Due to the high demand for financing different priority areas, such as health, disaster management as well as others, the government budgets are limited to offer the substantial amount of subsidy for renewable projects, and (b) Request for loans at flat rate and evaluating solar PV proposals within some few financial institutions and power utilities are non-existing [16]. Furthermore, the growth of SHS is also thwarted due to insufficient demonstration of the technology and the shortage of awareness among the SHS non-adopters through media, lack of effective promotional campaign and advertisement regarding the benefits that are experienced by SHS users, industry and among policymakers is considered as Informational barriers [7, 16]. Moreover, the rapid and smooth dispersion of SHS installations in rural Bangladesh is also impeded because of insufficient number of technical human experts on system installation, maintenance and running proper operation of SHSs as well as providing insufficient training program to SHS users [32].

Rural households have experienced some technical problems while using the SHS. An extensive household survey was conducted in remote areas among 630 clients of SHS about different problems they have been facing while using the solar home systems (SHSs) [2]. Figure 13 displays a graph showing the average number of problems experienced by SHS users over time [2]. The graph in Figure 13 depicts the number of problems faced by users depend on the operating time period of the SHS. The graph indicates an upward trend of the number of problems confronted by the users of SHS with an increase in time. Thus, it implies that since the installation of SHS in rural households, the quality and the efficient performance of the overall solar home system installed in the households has been degrading over time [2].

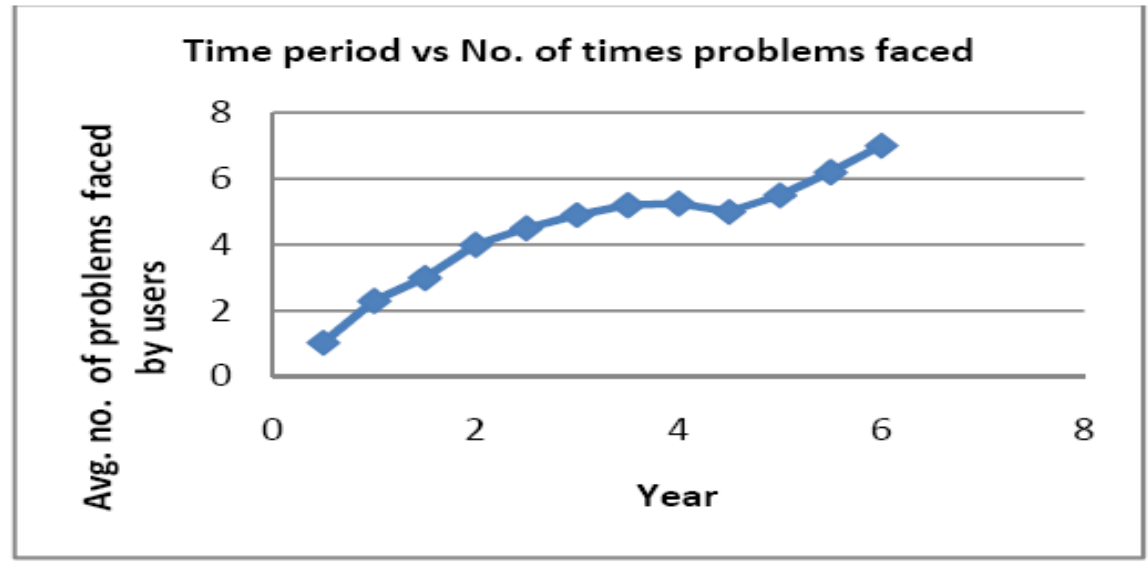

\section{Figure 13. Time Period vs No. of Times Problems Faced by Users [2]}

Technical Issues of SHSs which adopter-households have to tackle are considered as technical barriers. Poor quality components of the SHS such as PV panel, battery and charge controller in the market, lack of standard and quality control for SHS components, poor technical link in running the system and absence of technical expertise to support the 
development of SHS are involved as some technical barriers that are likely to hamper smooth running of SHSs in rural Bangladesh [16, 32]. Moreover, incorrect installation of a SHS unit, poorly designed SHS using inferior quality of SHS components and improper sizing of the system are responsible to demonstrate problems in the performance of the system [18, 19]. Partner Organizations (POs) have also experienced problems associated with poor technology and system components (battery and charge controller) as well as maintenance and management issues [19]. Due to the rapid growth of the SHS usage, while POs have to supply components of SHS regularly to meet the demand, some of the POs appear to lack sufficient institutional capacity and technical skills to manage installations of SHSs [34]. Hence, these issues are seemed to be responsible for problems that have recently accounted for by POs, involving inferior-quality components of SHS. An extensive BIDS/ World Bank 2012 survey was conducted among PO field offices and the survey results are displayed in Figure 14 [19].

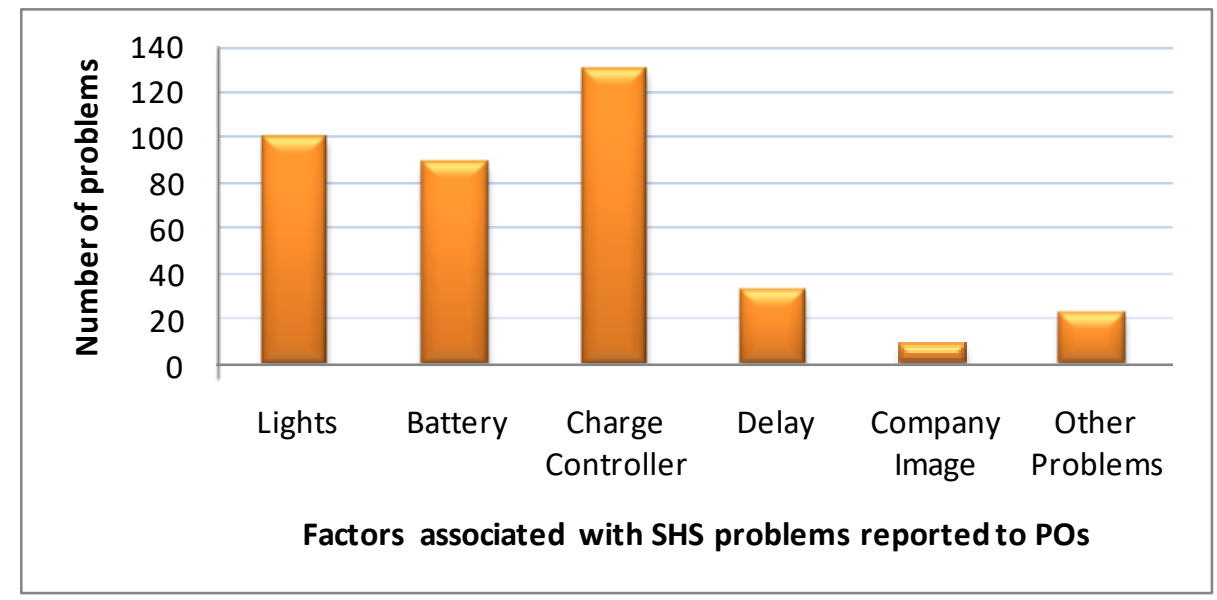

Figure 14. SHS Component Problems Reported to the POs Last Year [19]

The survey results in Figure 14 reveal that most of the POs have been reported with several number of problems because of poor-quality charge controllers (around 130 problems), lights (exactly 100 problems) and also having noticeable number of battery related problems (nearly 88 problems) during the last 12 months prior to the BIDS/World Bank 2012 survey. The findings of the survey among POs field offices in Bangladesh reveal that around $74.1 \%$ of the POs reported to have problems related to low quality lights/CFL bulbs, $96.3 \%$ of the POs have accounted to have problems regarding inferior quality charge controllers [18]. A significant figure of $69.2 \%$ of POs have got troubles with lower standard of battery and rest $37.8 \%$ have experienced problems related to delay of orders, company image and other problems [18]. Therefore, it can be concluded that concluded that the performance of the SHSs installed in households have been reduced due to poor installed standardization quality of the Solar Home Sys components, such as Lights, Battery and Charge Controller. Depending on the survey results as demonstrated in the Figure 8, it has also informed that SHS adopters also reported 22 other problems to POs which might be because of receiving poor after sale service and 32 problems delay in providing maintenance services, and few more problems were received by POs regarding poor company image in terms of providing proper and improved services to SHS adopted households.

Findings of the BIDS/World Bank survey 2012 has also illustrated that the household clients have experienced various types of problems regarding PV panel, charge controller and battery after installation of SHS. Figure 15 presents survey data of household clients who had to replace battery, charge controllers and PV panels during the 12 month period preceding the survey $[19,35]$. 


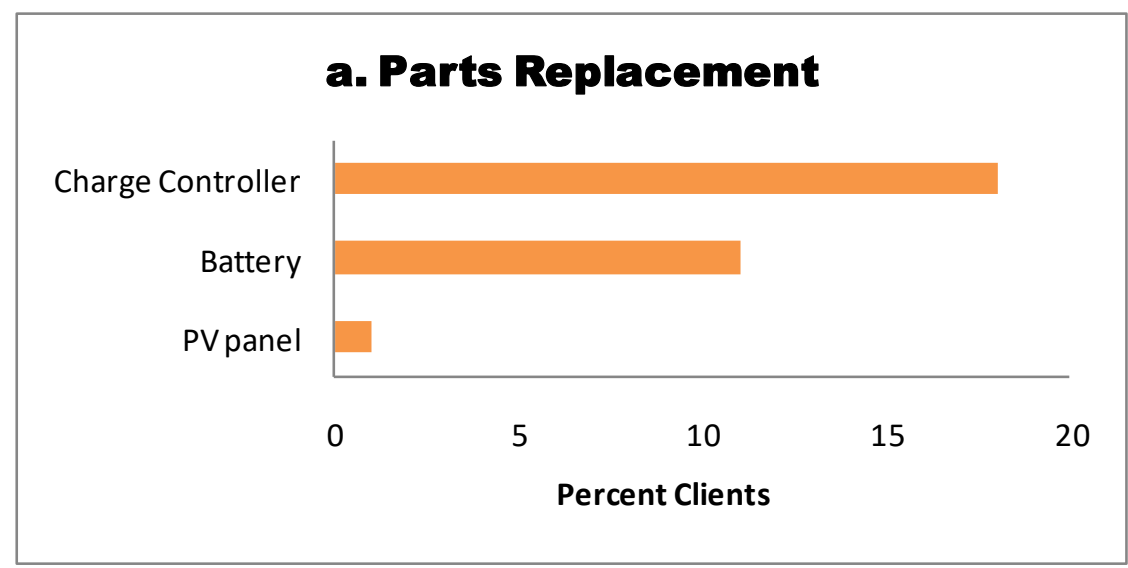

Figure 15. Clients Needing Replacement $[18,19]$

Among 1600 clients, the survey data displays that only 18 clients (1\%) have reported problems because they needed to replace PV panels. On the other hand, 287 customers (18\%) have required replacing damaged charge controllers and nearly 11\% (170 customers) have reported problems regarding battery replacement $[19,18]$. Thus, it can be implied that the quality of charge controllers and batteries have deteriorated with the passage of time. Figure 16 shows how many customers required major repair works of battery, PV panels and charge controllers during the last 1 year period prior to the survey $[19,35]$.

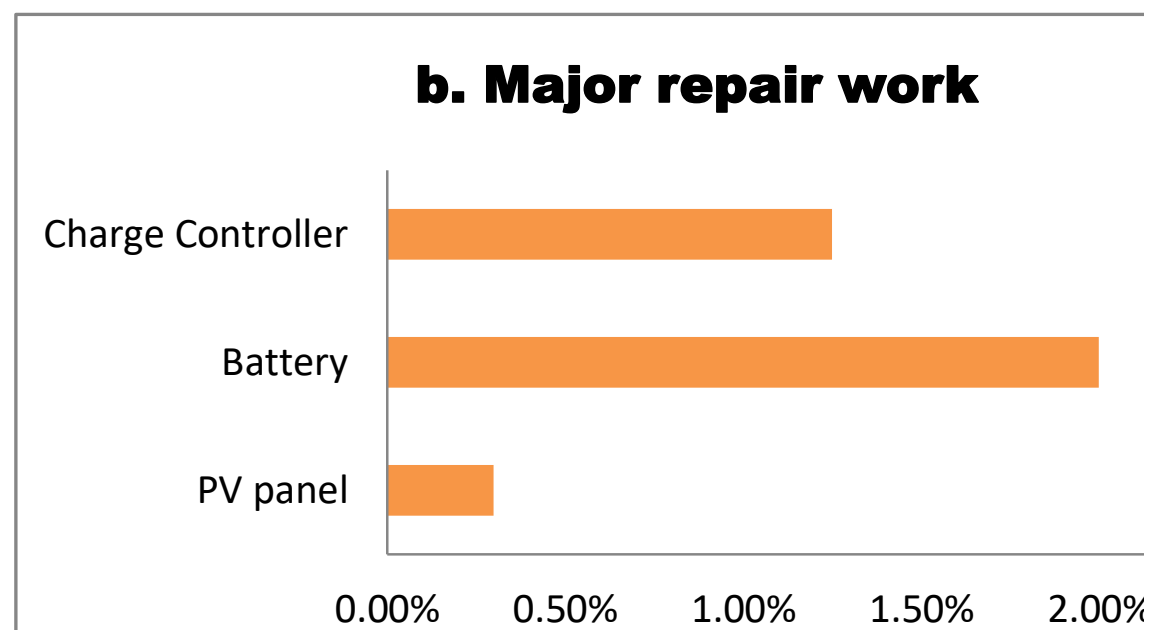

Figure 16. Clients Facing Problems Related to Major Repair Work [19, 35]

In case of charge controllers, the study has indicated that $2 \%$ SHS users required majority battery repair works. While, around $1.25 \%$ clients reported for the necessity to repair charge controllers. These repair works suggest that battery and charge controllers have been of inferior quality or operated improperly by users [19]. Even more than half of total customers surveyed, had to change tube lights compared to that of nearly $14 \%$ who changed their CFL lamps during 12 month period prior to the survey [19].

Furthermore, there are also some challenges of the SHS that affect the smooth progress of SHS installation in Bangladesh. Although it is the responsibility of POs and other SHS service providers to do servicing, SHS users do not receive any proper and sufficient technical training on the maintenance of the SHS [2]. Due to the lack of education-cum awareness of SHS adopters, they tend to misuse the components of the SHS during the operation of the system which causes premature problem of the system [18]. Besides, users 
of SHS have got very insufficient knowledge about Tilt angle of PV panel during SHS installation and they lack required consciousness about changing of the panel position with change of seasons [11]. Thus, SHS users do not get efficient power generation because of not maintaining proper Tilt angle during installing the SHS. Insufficient backstopping services are provided by POs on the benefits of titling PV module during summer and winter season to obtain the maximum power from the SHS [18]. Due to poor services that are provided to the SHS households by different POs and various SHS service providers in various rural areas, customer satisfaction has decreased. Figure 17 shows a survey result that was conducted in less remote areas, high remote village of Teparia and medium remote area [2].

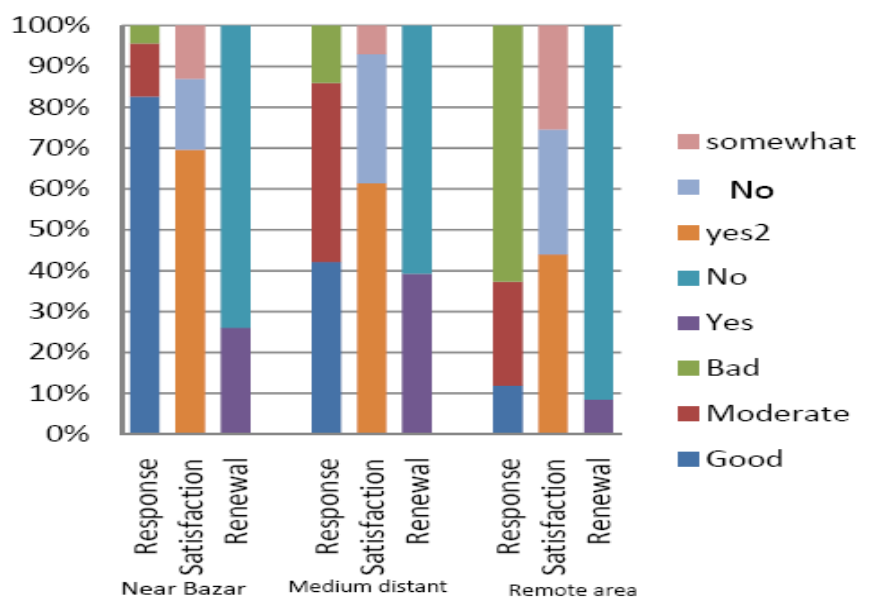

\section{Figure 17. Graph Showing User Satisfaction, Service Providers Response \& Users' Renewal Decision based on Remoteness [2]}

A total of 630 SHS clients were surveyed related to their level of satisfactions about services they have received after SHS adoption and also their willingness to renew usage of the SHS [2]. The graph depicts that in high remote areas, the service response of service providers is much lower (about 12\%) than the less remote areas (about 42\%). Similarly, these customers' satisfaction of in highly remote areas have been found to be less (nearly 43\%) than that of in less remote areas (around 61\%). Besides, the survey results also reveal that users of SHS in highly remote areas are reluctant to increase their connections because of unreliable services from service providers of SHS. Thus, these factors affect the progress of SHS in remote areas.

Since the numbers of installations of SHSs have been incremented over the years, many local and foreign manufacturers have started doing business, producing components of SHS to make profits. Hence, the overall quality of components varies across the manufacturers resulting in the system inefficiency due to lack of maintaining standard quality of components [18]. Besides, the lack technical management capability and the lack of skilled force are also acting as obstacles affecting the booming of SHS. This is evident by the fact that according to KFW report, there were $4 \%$ deficient installations of SHS during July 07- August 08 and the figure has increased up to $7 \%$ deficiency between November 09- February 11 [18].

Progress of SHS in urban areas gets failed because of lack of technical suitability to produce electricity using the solar PV panel. Only $7.86 \%$ of the total land in urban areas, such as Dhaka city as well as others is suitable for producing electricity using solar PV [36]. People living in urban areas get access to supply of grid electricity. Moreover, considering grid availability in other urban areas such as Chittagong district and other districts, only $1.7 \%$ of the land in Bangladesh is presumed to be technically suitable for using solar PV technology for accessing power [37]. Hence, regarding technical suitability 
of using solar area along with grid-electricity, the failure of SHS growth in urban areas persists. Besides, the progress of SHS has also become unsuccessful, considering financial infeasibility of using the solar PV in urban areas. Failure of the SHS in urban areas is also due to its little payback to users of the SHS. Since majority of the populations living in urban areas are highly dependent on grid-supply electricity, usage of SHS is very limited. Even though, SHS users will be able to get electricity access, they tend to use SHS for few hours during the load shedding period for only the purpose of lighting. Considering the high initial costs of investment on the solar PV panel which customers need to pay for the SHS, the time it takes to receive benefits of payback is very longer than expected.

Not only in urban areas, in the 2014-15 and 2015-16 fiscal years the market expansion of SHSs also dropped dramatically because of the prompt expansion of grid electricity supply in many rural areas. In the recent years, Bangladesh Rural Electrification Board (BREB) expanded its grid supply in many off-grid areas causing significant decline in the number of SHSs installations by IDCOL in these off-grid areas. Figure 18 illustrates the impact of the grid connection in many off-grid rural areas on the installations of SHSs in every year by IDCOL. From the year of 2014, the installations in these rural areas declined by $30 \%$ within the one year to 451,623 [38]. Subsequently, the result of rapid expansion of the grid connection to 47.39 lakh users in many rural off-grid areas has also led to further decline of SHSs installation in these areas by 56\%, with only125,899 SHSs have been installed in off-grid areas by IDCOL between Jan 2016 and June 2016 [38]. In order to overcome the decline and failure of SHS installations in these rural areas where grid supply is connected, IDCOL has initiated another program of installing "plug and play systems" in very low-income earning rural households who are not capable to afford electric supply from grid and SHSs.

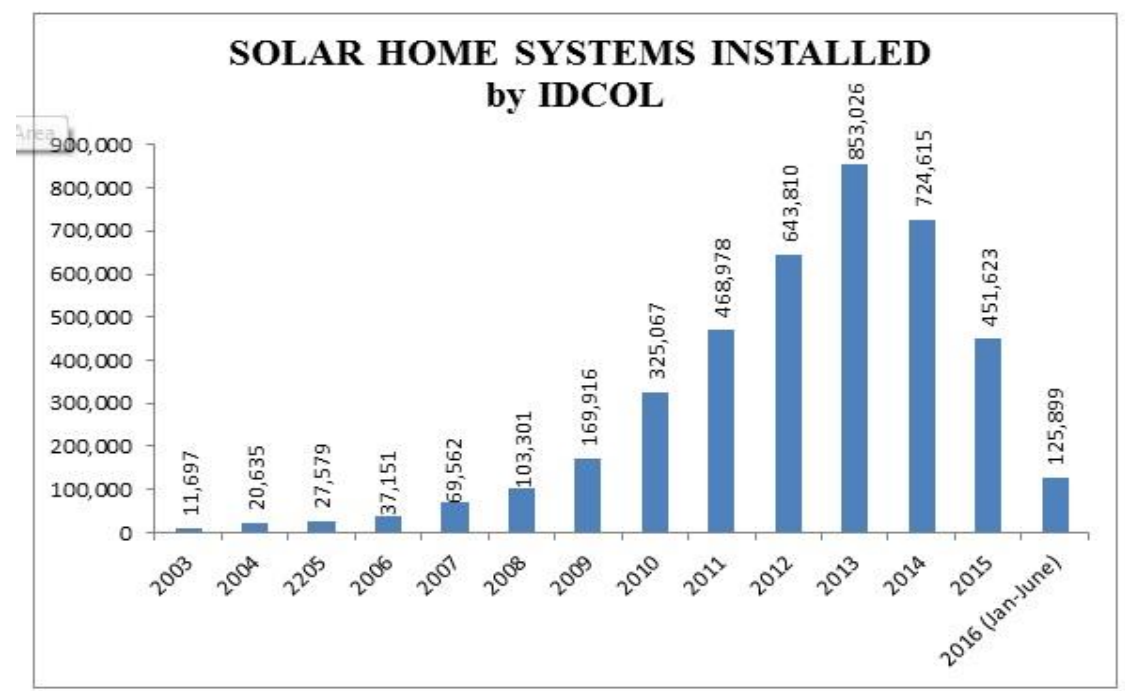

Figure 18. Impact of grid-connection of the Number of SHSs Installations by IDCOL [38]

\section{Prospects of SHS in Rural Bangladesh}

Considering the rate of substantial growth of the SHS in rural areas over the last couple of years, it is possible to predict the significant expansion of SHSs in the near future in Bangladesh. Around 2 million SHSs were installed having a total generation capacity of around $94 \mathrm{MW}$ till December 2012 under financing of IDCOL [2]. Under the IDCOL's SHS program, around 60,000 SHSs had been installed in every month at the end of the year 2013. If this SHS expansion rate can be continued, it is estimated that the total generation capacity from the IDCOL's SHS program will reach about $200 \mathrm{MW}$ by the end 
of December, 2015 [2]. Figure 19 shows the exponential increase in the cumulative power generation from SHSs installation 2003 and the predicted power generation by the end of the year 2015, if the current rate of installations is maintained [2]. Depending on the decrease in the number of SHS installations between 2014 and 2015 as shown in figure 18, the estimated total power generation by the end of the year 2015 can hardly be achieved through dissemination SHS program according to the initial projected value by the IDCOL. Nevertheless, the substantial number of SHS installations in recent years (2015) has contributed to increasing the total power generation by SHS and will lead to gradual increase in production of power in the coming years.

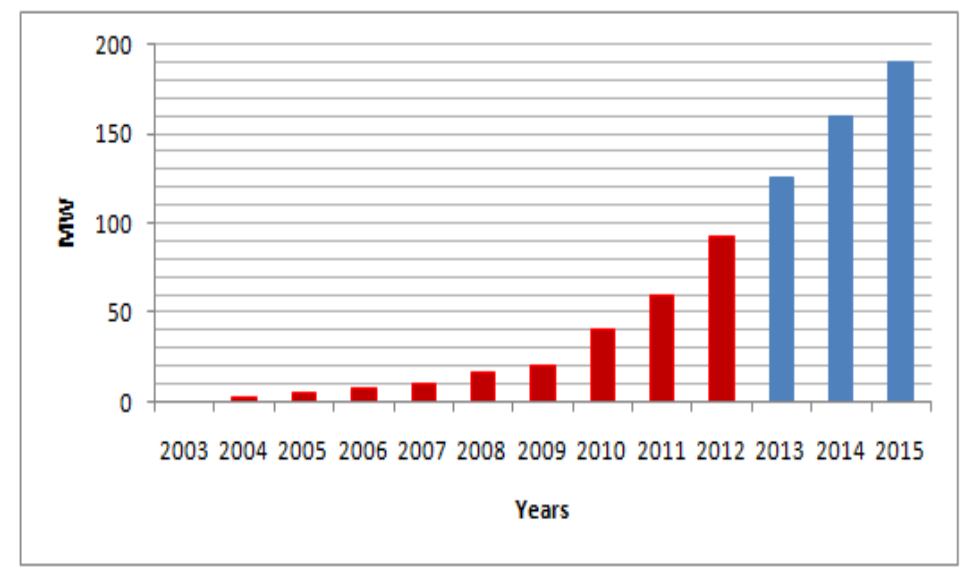

\section{Figure 19. Cumulative Power Generation from SHSs [2]}

At present, the IDCOL has aimed a new target of financing a total of 4 million SHSs within the year of 2015 [2]. Following the current pace of installations, the cumulative total number of SHSs installations from 2013 to 2015 should reach up to 3,8882,868 [10]. Hence, it shows that with a little extra effort, IDCOL can achieve its revised target of 4 million installations of SHSs by 2015. IDCOL has played a vital role to fulfill this revised target. By the end of May 2016, IDCOL have already been able to install exactly 4,013,524 SHSs up to May 2016 and the new goal is to fulfill the target of 6 million SHS installations by the end of the year 2016 [39]. Besides, being the lead initiator in the development and diffusion of SHSs technology, IDCOL is expected to contribute a total of 234 MW additional capacity SHSs with the involvement of private and various non-governmental organizations to fulfill its new objective of 6 million SHSs installation within 2-3 years [40, 41]. Moreover, IDCOL has recently taken initiative to diffuse "plug and play solar home system" for very low income rural households. On June 30, 2016, IDCOL has recently signed a contract with Sustainable \& Renewable Energy Development Authority (SREDA) to conduct a project with the aim to install 100,000 solar plug and play systems [42]. The successful completion of the project will provide access to electricity for very low income households who do not have the capability to afford a SHS. IDCOL will receive a grant of USD 2 million for dissemination of plug and play systems at rural households and this grant will more likely to help very poor people to afford the system at a very cheaper and affordable price [42]. The beginning of this program is very promising for the future endeavors of these authorities in Bangladesh to spread the access to electricity for all income groups of people.

The future potential of the present market of SHS is large and very promising in Bangladesh for promoting electrification in the remote areas where chances of expanding grid electricity is unlikely to happen in the foreseeable future. The favorable economic feasibility and viability of SHS installations for the future is also one of the key indicator for the future growth of SHS in rural Bangladesh. A survey was conducted on the 
economic and financial feasibility analysis on SHS installation for lighting facility by replacing kerosene based lighting. Due to the replacement of kerosene by SHS, the survey results found shorter payback period ranging around 1.13 to 2.37 years for different SHS installation capacity of around $20 \mathrm{Wp}$ to $42 \mathrm{Wp}$ [32]. According to the survey data it was also revealed that by replacing expensive usages of kerosene, the total predicted high costs incurred by the kerosene for using 20 years exceeds the initial installation costs of a SHS unit in a rural household, considering the replacement lifetime for solar panels are 20 years. Therefore, it can be concluded that the prospect of installing SHS in upcoming future over the rural areas will keep on thriving due to the shorter payback period which reduces the chances of uncertainty of SHS installations in non-SHS adopted households because of faster recovery of initial investment. There is an ample scope for the continuous expansion of SHS for electrification in many available off-grid areas. Due to the unreliable supply of electricity in on-grid areas and considering the high transmission costs to generate electricity in remote areas, the future size of the SHS market is anticipated to increase in the foreseeable future with the possibility of coverage in all off-grid areas in Bangladesh [43]. The probability of purchasing a new unit of SHS by current users is a good indicator of market demand for SHS. A contingency valuation (CV) method is found to be useful to predict the market demand for SHS [42]. Depending on the results of the purchase behavior of customers from the $\mathrm{CV}$ method, the probability of purchasing different capacity of SHSs has been estimated. Table 6 shows predicted probability of purchasing a SHS unit by non-SHS users and how the estimated buying probability of existing SHS users varies due to the changes in SHS capacity [43].

\section{Table 6. Predicted Probability of Purchase by SHS users \& Non-users} [43]

\begin{tabular}{|l|c|}
\hline Household Type & Probability of Purchase (\%) \\
\hline SHS users, capacity \& ownership & \\
\hline $40 \mathrm{Wp}$ & 10.5 \\
\hline $50 \mathrm{Wp}$ & 12.5 \\
\hline $65 \mathrm{Wp}$ & 14.7 \\
\hline All SHS users & 12.5 \\
\hline All SHS non-users & 62.0 \\
\hline All households & 58.4 \\
\hline
\end{tabular}

The data in the Table 6 indicates that the chances of buying an additional unit of SHS by the users is less as the predicted probability of buying an additional SHS unit is only $12.5 \%$. In contrast, SHS non-users have greater tendency to buy a SHS unit as the estimated probability of buying is significantly high (62\%). Besides, the result in Table 6 shows that the overall predicted probability of purchase is $58.4 \%$ in rural off-grid market. Therefore, it clearly point out about the huge market potential of SHS in rural Bangladesh.

Because of the fact that a total of 1.3 million households had adopted a SHS at the time of BIDS/World Bank survey 2012, applying 58.7\% of purchasing probability to remaining 13.7 million non-adopted rural households results the total market size to reach 7.95 million which is 5 times larger than the customer base in 2012 [43]. Price of a SHS unit is one of the major factors, which determine the future prospect of SHS in rural Bangladesh. Reduction in price of a SHS unit will be a significant driver for the future market growth of SHS. Figure 20 displays a graphical representation of estimated sales of SHS in future as 
well as variations in probability of purchase based on the decrease in the price of SHS [43, 35].

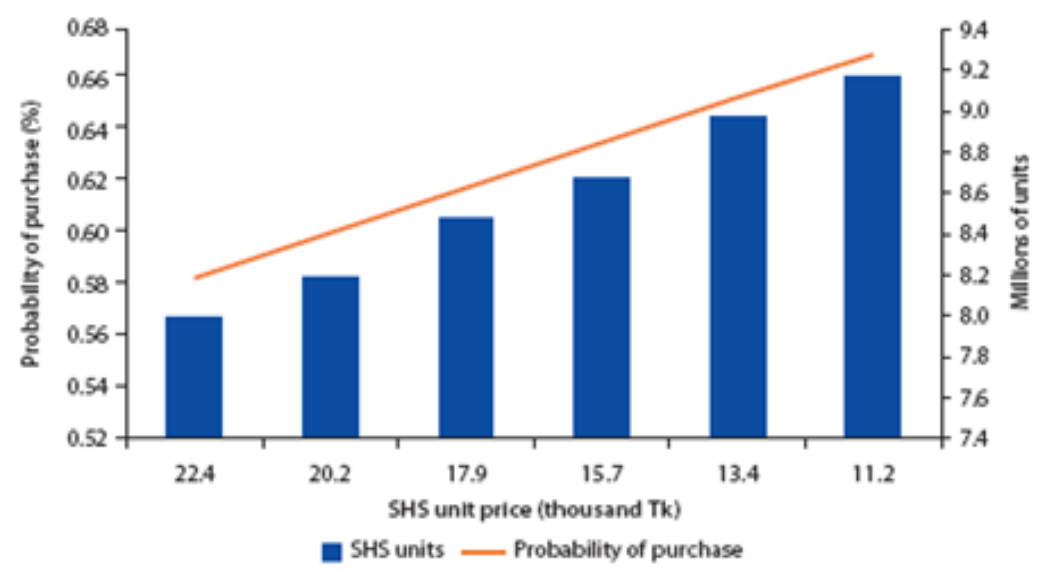

Figure 20. Trends in Probability of Purchase \& Potential Sales due to Price Drop $[43,35]$

The graph presents a linear increment in the probability of purchasing a SHS unit based on it's the price drop. Figure 20 reveals that if the price of a SHS unit falls by $50 \%$, from BDT. 22,400 to BDT 11,200 , the probability of buying a SHS unit increases by $9 \%$ reaching a value of $67 \%$. As a result, the predicted sales of SHS will be boosted from 8 million to 9.3 million.

Besides, a huge prospect of SHS in off-grid and remote areas is also exemplified by clear indicative steps that have been taken by the government and other policy-makers. In order to develop renewable energy resources \& technology including the solar PV, the government of Bangladesh has set a target of generating 5\% of the total power demanded from renewable resources by 2015 [44]. In order to achieve the target as outlined in the Power system master plan 2010, the government of Bangladesh has given importance in extraction of energy from renewable resources including solar energy in order to develop $500 \mathrm{MW}$ solar powered programs. Under this program, it is expected that with the contribution of both public and private sectors of the government, solar electrification for both residential and social purposes in remote areas will be established and implemented in significant capacity [40]. Considering the ongoing popularity for rural electrification by means of installing SHS, the government has also started a solar powered program in a broader scale for fulfilling the target of producing a total of 1739.75 MW capacity by the end of the year 2021, which will involve construction and implementation of solar energy based projects including SHSs household electrification [45]. Moreover, the government has taken some steps to ensure efficient use of renewable energy technology. The government has improved some building code by taking into considerations of issues related to the potential use of solar energy. In the renewable energy policy (REB) 2008, the Bangladeshi government has declared to produce $10 \%$ power from renewable energy sources within the year of 2020 [16]. For stimulating the PV market and to promote the widespread of this market, according to the REB 2008, renewable energy project investors will be exempted from corporate income tax for next 5 years [16]. Hence, POs shall be encouraged to continue doing their business of installing SHS in remote areas in the future. There is a greater possibility of further successful diffusion \& implementation of SHS in the future in many rural areas because of employing some effective market strategies such as financing scheme [6]. Concomitantly, the different types of options for paying money in installments are also attracting even the very low income earning non-users to install a SHS unit. Attracting non-SHS users for buying and installing SHS allows the POs and 
renewable energy regulatory authorities to continue an uninterrupted expansion of SHS in off-grid rural areas for ensuring these rural off-grid villages can be provided with the required access of electricity using the solar energy. Subsequently, the government has also decided to extend ongoing financing facilities for the renewable energy in the REP 2008 to provide financing for investments on the renewable energy [16]. Therefore, all these policies suggest a tremendous future potential of the SHS market in rural Bangladesh.

The feasibility of implementing a future-scaled program can be enhanced and ascertained by carrying out standard-testing to maintain the standard quality of SHS components [34]. The future potential of developing reliable SHS units with enhanced technology and improved life cycle is likely to be on the right path because of recent attempts of IDCOL with Bangladesh University of Engineering and Technology (BUET) for setting up a PV testing facility in Bangladesh [19]. Moreover, the recent significant technological innovations of SHS over the last few years provide a positive indication that the future development of the SHS market in Bangladesh will most like continue in the future [43]. Technological improvement has allowed adoption of energy-efficient lightemitting diode (LED) technology to run LED lights using SHS [19]. Usages of LED lights require a lower capacity SHS unit such as $20 \mathrm{Wp}$ for household lighting to provide the same intensity of lighting needs that could have been provided by a high price $40 \mathrm{Wp}$ SHS unit. Hence, the demand of $20 \mathrm{Wp}$ has been increased since the starting of LED technology in early 2011 [19]. Thus, the rising trend in technological innovation and improvement of the SHS technology has been major deciding factors towards the brighter prospect to spread usages of SHSs in rural Bangladesh.

\section{Conclusion}

Energy demand in Bangladesh is rising swiftly every day because of the population growth and consequently to meet the requirement of higher consumption. The rate of ongoing rising demand for power exceeds the capacity to produce grid electricity, using only non-renewable resources such as fossil fuel and others. Absence of transmission and distribution of on-grid electricity in many rural areas are responsible for the continuous energy crunch in Bangladesh. Many remote villages are being deprived of accessing the supply of grid electricity because of high transmission costs as well as distribution costs of electricity. As a result, the load and the requirement for power in these areas do not match with each other [16]. Hence, considering the financial feasibility to provide on-grid supply of electricity, power utilities appear to have failed to provide electrification in many remote villages.

The energy crisis in many rural areas needs to be improved to assure social and economic development among the people. Solar Home System (SHS) is an alternative solution to fulfill the demand for the household lighting. Adoption of a SHS unit enables a convenient and sustainable way of accessing a high-quality, clean and environmentfriendly energy service. The paper has discussed the tremendous increase in installations of SHSs among the rural households in many remote areas. As a result, the SHS has gained its popularity over time particularly in various rural places [2]. The quantity of SHS installation is linked with remarkable direct and indirect socio-economic benefits of SHS on the lives of the rural people. The existing proper regulatory and policy framework by the policy makers to ensure smooth installation progress of SHS in every rural household. By using the survey data, this paper has explained the socio-economic positive benefits for operating a SHS unit in rural villages, including the high-quality household lighting, extended hours of education, and better health related awareness among women through watching TV and income generation opportunities. Moreover, unlike kerosene the usage of the SHS does not contribute to household pollution. Solar Home System (SHS), using the 
renewable energy resource, known as the solar energy, does not contribute to global warming.

However, some constrains have been noticed which are slowing the diffusion of SHSs in rural areas. High initial costs of installing a SHS unit, poor backstopping service of POs and poor quality of SHS components including batteries, charge controllers and PV panels are constraints that tend to hamper the growth of the SHS market in Bangladesh. Moreover, the power output reduction due to shading, inefficient service due to dust accumulation are some of the challenges, which are posing significant threats to the widespread of SHS in Bangladesh [2]. Furthermore, there are few barriers, for instances: lack of receiving sufficient technical training from POs, lack of proper awareness on maintenance SHS users and others are also responsible for experiencing problems while operating a SHS unit, causing dissatisfaction among SHSs adopted households. Adoption of the SHS has got huge potential in Bangladeshi remote areas. In order to make sure of the substantial growth of SHS in every rural place, it is essential to overcome the barriers and existing problems of the SHS. IDCOL needs to work with its technical standard committee to set required standards, and to push local Bangladeshi assemblers with the aim to improve the quality of their products of SHS so that they can develop good quality PV panels in the local markets [19]. Besides, producing better quality SHS components by focusing on designing components with better reliability can be an effective approach to minimize manufacture of low quality SHS components [18]. The government of Bangladesh can play huge role to promote future growth of SHS by instituting a financing mechanism in favor of SHS diffusion, offering temporary tax exemption to help the rural people to buy components of SHS and providing subsidies to ensure that the future expansion of SHS reach poorer segment of the rural population along with the relatively better-off rural households in Bangladesh [16, 19]. The existing financing schemes also need to be more regulated and modified according to the needs of the very poorer rural people who are still living without electricity in off-grid areas, so that the financing obstacles can no longer hamper the rapid SHS growth in the future.

\section{Acknowledgments}

These Special thanks go to BRAC UNIVERSITY for providing financial support to carry out components testing of Solar Home System (SHS) in the laboratory at BRAC University. Much gratitude goes to research assistants and project engineers of Control \& Applications Research Centre (CARC) for carrying out their technical assistances regarding the SHS project. Control \& Applications Research Centre (CARC) wishes to thank and appreciate relentless efforts of these personnel who have been involved in this SHS project.

\section{References}

[1] M. A. H. Mondal, "Implications of renewable energy technologies in the Bangladesh power sector: Longterm planning strategies", Ph.D. dissertation, Dept. of Ecology and Natural Resources Management, ZEF, University of Bonn, Germany, (2010) July.

[2] M. Islam, R. Shameen, A. Mashsharat, M. S. Mim, M. F. Rafy, M. S. Pervej and M. D. Ahad, "A Study of Solar Home System in Bangladesh: Current Status, Future Prospect and Constraints", Proceedings of 2nd International Conference on Green Energy and Technology, (2014) September.

[3] C. K. Das and M. J. Alam, "An Innovative Energy Neutral Home System for Rural Areas of Bangladesh", 7th International Conference on Electrical and Computer Engineering, (2012) December 20-22.

[4] R. Rash-Ha Wahi and N. U1 Ahsan, "Feasibility Study of Solar Home System in Rural Areas of Bangladesh: Prospect, Progress and Challenges", Proceedings of the Global Engineering, Science and Technology Conference, Dhaka, Bangladesh, (2012) December.

[5] M. Ahmed, A. S. M. Hasan, Md. Habibullah and S. Ahmed, "Solar PV Energy Achievements and Prospects in Development of Rural Bangladesh", International Journal of Science and Research (IJSR), India.

[6] S. Rahman and M. Ahmed, "Solar Home System (SHS) in rural Bangladesh: Ornamentation or fact of development?", Energy Policy, vol. 63, (2013) August, pp. 348-354. 
[7] F. Ahammed and A. Azeem, "Selection of the most appropriate package of Solar Home System using Analytic Hierarchy Process model in rural areas of Bangladesh", Renewable Energy, vol. 55, (2013) January, pp. 6-11.

[8] Md. Biswas, K. Das, I. Baqi, M. Sadi and H. Farhad, "Prospects of Renewable Energy and Energy Storage Systemsin Bangladesh and Developing Economics", Global Journal of researches in engineering: J General Engineering, vol. 11, no. 5, (2011) July.

[9] D. Kanama and H. Kawamoto, "Research and development trends of solar cell for highly efficiency", from Nanotechnology and Material Research Unit, (2008) July.

[10] Md H. Ullah, T. Hoque and Md M. Hasib, "Current Status of Renewable Energy Sector in Bangladesh and a Proposed Grid Connected Hybrid Renewable Energy System", International Journal Of Advanced Renewable Energy Research, vol. 1, no. 11, (2012), pp. 618-627.

[11] A. Sultana Al-Amin, J. Hasan, Md. T. Islam and F. Khan, "Solar Home System in Bangladesh: Prospects, Challenges and Constraints", 3rd International Conference on the Developments in Renewable Energy Technology, (2014) May.

[12] I. Sharif and M. Mithila, "Rural electrification using PV: the success story of Bangladesh", Energy Procedia, vol. 33, (2013), pp. 343-354.

[13] M. A. S. Mondal, L. M. Kamp and N. I. Pachova, "Drivers, barriers and strategies for implementation of renewable energy technologies in rural areas of Bangladesh an innovative system analysis", Energy Policy; vol. 38, no. 8, (2010), pp. 4626-34.

[14] Ministry of Power, Energy and Mineral Resources, Govt. of the Peoples Republic of Bangladesh, Renewable energy policy of Bangladesh, Dhaka, Bangladesh, (2008) November.

[15] A. K. Azad, "A Review on Renewable Power Sources: Prospects of Bangladesh and Scotland", (2011), [Online]. Available: http://pdfmio.com/download/renewablepower [ Dec 30, 2014].

[16] M. Z. Rahman, "Multitude of progress and unmediated problems of solar PV in Bangladesh", Renewable and Sustainable Energy Reviews, (2011) September, pp. 466-473.

[17] S. Chakrabarty and T. Islam, "Financial viability and eco-efficiency of the solar home systems (SHS) in Bangladesh”, Energy, vol. 36, no. 8, (2011), pp. 4821-4827.

[18] M. Asaduzzaman, M. Yunus, A. K. Enamul Haque, A. Malek Azad AKM, S. Neelormi and M. Amir Hossain, "Power From The Sun: An Evaluation of Institutional Effectiveness and Impact of Solar Home Systems in Bangladesh", Washington DC, (2013) May 30.

[19] R. Shahidur, H. A. Samad, Z. K. M. Sadeque, M. Asaduzzaman, M. Yunus and A. K. Enamul Haque, "Developing a Sustainable Market", Surge in Solar-Powered Homes: Experience in Off-Grid Rural Bangladesh, Directions in Development, Washington, DC: World Bank, (2014) October 20, pp. 77-86.

[20] E. Martinot, R. Ramankutty and F. Rittner, "The GEF Solar PV Portfolio: Emerging Experience and Lessons", Global Environmental Facility, Monitoring and Evaluation Working Paper 2, Washington D.C., (2000).

[21] M. S. Hossain, M. Rahman, A. K. M. Z. Islam and M. F. Hassan, "Strategy for Promotions and Development of Wind Energy in Bangladesh", Proceeding of the National Seminar on Renewable Energy 2011. Dhaka, Bangladesh, (2011) April 6-8.

[22] M. S. Kaiser, M. A. Rahman, M. M. Rahman and S. A. Sharna, "Wind energy assessment for the coastal part of Bangladesh", Journal of Engineering and Applied Sciences, vol. 1, no. 2, pp. 87-92.

[23] "Renewable energy projects, IDCOL solar energy program". Internet: http://www.idcol.org/prjshsm2004.php, March 2012 [June 10, 2015].

[24] I. Sharif and M. Mithila, "Rural electrification using PV: the success story of Bangladesh", Energy Procedia, vol. 33, (2013), pp. 343-354.

[25] R. Shahidur, H. A. Samad, Z. K.M. Sadeque, M. Asaduzzaman, M. Yunus, A. K. Enamul Haque, "Surge in Off-Grid Solar-Power Homes", Surge in Solar-Powered Homes: Experience in Off-Grid Rural Bangladesh, Directions in Development, Washington, DC: World Bank, (2014) October 20, pp. 9-17.

[26] IDCOL. Dhaka, Bangladesh: Infrastructure Development Company Limited. Internet: http:// www.idcol.org/news_detail.php?id1/469; 2011 [January. 02, 2014].

[27] Renewable Energy Policy OF Bangladesh, Power Division: Ministry of Power, Energy and Mineral Resources. (2008) December 18.

[28] S. N. Uddin and R. Taplin, "A sustainable energy future in Bangladesh: current situation and need for effective strategies", Proceedings of the second joint international conference on sustainable energy and environment, (2006), pp. 21-23.

[29] S. R. Khandker, H. A. Samad, Z. K. M. Sadeque, M. Asaduzzaman, M. Yunus and A. K. Enamul Haque, "Welfare Impacts of Household Adoption", Surge in Solar-Powered Homes: Experience in Off-Grid Rural Bangladesh, Directions in Development, Washington, DC: World Bank, (2014) October 20, pp. 4959.

[30] S. R. Khandker, H. A. Samad, R. Ali and D. F. Barnes, "Who Benefits Most from Rural Electrification?", Energy Journal, vol. 33, no. 2, pp. 75-96.

[31] S. Mollik, M. M. Rashid, M. Hasanuzzaman, M. E. Karim and M. Hosenuzzaman, "Prospects, progress, policies, and effects of rural electrification in Bangladesh", Renewable and Sustainable Energy Reviews, vol. 65, (2016), pp. 553-567. 
[32] P. K. Halder, "Potential and economic feasibility of solar home systems implementation in Bangladesh", Renewable and Sustainable Energy Reviews, vol. 65, (2016), pp. 568-576.

[33] R. Posorski, M. Bussman and C. Menke, "Does the use of Solar Home Systems (SHS) contribute to climate protection?", Renew Energy, vol. 28, (2003), pp. 1061-1080.

[34] S. A. Khan, R. Rahman and A. Azad, "Solar Home System Components Qualification Testing Procedure and Its Effects in Bangladesh Perspective", Proceedings of IEEE Global Humanitarian Technology Conference: Technology for the Benefit of Humanity, Seattle, (2012) October 21-24.

[35] BIDS/World Bank, "Household Survey Data on Impact Evaluation of Solar Home Systems in Bangladesh”, Bangladesh Institute of Development Studies and World Bank, Dhaka, (2012).

[36] M. H. Kabir, W. Endlicher and J. Jagermeyr, "Calculation of bright roof-tops for solar PV applications in Dhaka Megacity, Bangladesh", Renewable Energy, vol. 35, (2010), pp. 1760-4.

[37] B. Sorensen, "GIS management of solar resource data", Solar Energy Materials and Solar Cells, vol. 67, (2001), pp. 503-9.

[38] S. Parvez, "Solar energy dims as grid power expands", Daily Star, pp. 17, August 25, 2016, Internet: http://epaper.thedailystar.net/index.php?opt=view\&page=17\&date=2016-08-25. [Accessed on: August 30, 2016].

[39] A. Batteiger, "Towards a Waste Management System for Solar Home System in Bangladesh", Conference MES-BREG, Centre for Technology and Society, (2014), pp. 149-150.

[40] P. K. Halder, N. Paul, M. U. H. Joardder and M. Sarker, "Energy scarcity and potential of renewable energy in Bangladesh", Renewable and Sustainable Energy Reviews, vol. 51, (2015), pp. 1636-1649.

[41] Renewable energy in Bangladesh, Internet: http://www.powerdivision.gov.bd/user/ brec/49/89, 2015. [Accessed on: June 25, 2017].

[42] "IDCOL to play plug and play solar system to low income household", Internet: http://energynewsbd.com/details.php?id=636, June 30, 2016. [Accessed on: July 10, 2016].

[43] S. R. Khandker, H. A. Samad, Z. K. M. Sadeque, M. Asaduzzaman, M. Yunus and A. K. Enamul Haque, "Market Analysis and Role of the subsidy", Surge in Solar-Powered Homes: Experience in Off-Grid Rural Bangladesh, Directions in Development, Washington, DC: World Bank, (2014) October 20, pp. 6176.

[44] M. Riazul Hamid, "Photovoltaic Based Solar Home Systems - Current State of Dissemination in Rural Areas of Bangladesh and Future Prospect", International Journal of Advanced Research in Electrical, Electronics and Instrumentation Engineering, vol. 2, no. 2, (2013) February.

[45] Md. A. H. Baky, Md. M. Rahman and A. K. M. S. Islam, "Development of renewable energy sector in Bangladesh: Current status and future potentials", Renewable and Sustainable Energy Reviews, vol. 73, (2017), pp. 1184-1197.

\section{Authors}

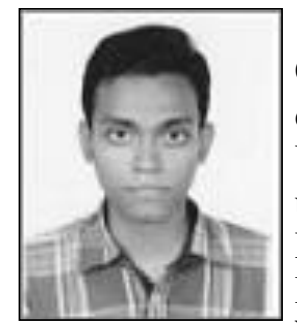

Jaber Al Rashid, is currently working as a "Research Assistant" at Control and Applications Research Centre (CARC), under the department of Electrical and Electronic Engineering (EEE) at BRAC University, since September, 2016. Upon the completion of his undergraduate degree in Electrical and Electronic Engineering from BRAC University, since September, 2015, he has also worked at BRAC University as a "Research Engineer" till August, 2016. Working as a Research Engineer, he has conducted and supervised numerous projects related to renewable energy technology and vehicular technology. Jaber Al Rashid completed his 4 years of undergraduate study in EEE at BRAC University in 2015. He did his major in Electronics and Computer group and currently his research interest is in Renewable Energy technology and its applications, Energy Efficiency and Energy Storage System. During his academic career, he also worked as a part time Teaching Assistant (TA) at BRAC University. Prior to his undergraduate enrollment at BRAC University, he completed GCE O Level in 2008 and GCE A Level in 2010 under the Edexcel International Board. 


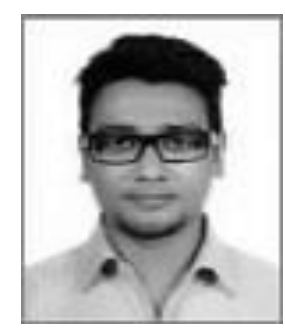

Ataur Rahman, is currently working as a "Project Engineer" at Control \& Applications Research Centre (CARC), under the department of Electrical and Electronic Engineering (EEE) at BRAC University since October, 2016. He also worked as a "Research Engineer" under the same institution from September, 2015 to August, 2016. He completed his 4 years of undergraduate degree in Electrical and Electronic Engineering from BRAC University in 2015. He did his major in Electronics and Computer group, and currently his research interests are in Renewable Energy, Automotive Systems, Energy Storage Technology and Efficiency. Working both as a project engineer and a research engineer, he has got ample experience in managing and supervising research groups to supervise and different types of research activities and projects.

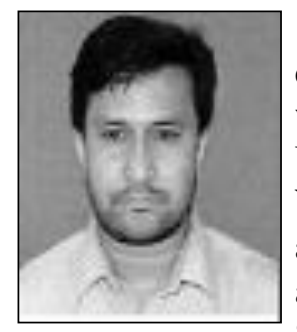

Dr. A.K.M Abdul Malek Azad, is currently a Professor in the department of EEE, BRAC University. From 1992 till 2006, he has worked as an academia (undertaking casual teaching) for Macquarie University, The University of New South Wales, University of Western Sydney and Institute Technology Pekerja. He also worked as a consultant (Engineering) for the World Bank Project "Productivity and Efficiency of Solar House Panels in Bangladesh: Economic, Social and Food Security Implications" associated with BIDS (Bangladesh Institute of Development Studies). He is the founder and director of the Control \& Applications Research Centre (CARC), under the department of EEE, BRAC University, where he has also been the initiator of the synergy program between BRAC and BRAC University undertaking numerous research projects e.g. solar home system component testing for IDCOL, performance analysis of BRAC Solar PV modules, etc. He is also the founder and counselor for the IEEE Student Branch at BRAC University. He also worked as a Development Engineer for a biomedical engineering project (Direct Cardiac Compression Device) with HEART ASSIST TECHNOLOGY Pty LTD (Australia) in collaboration with Professor Stephen N. Hunyor, Director, Cardiac Technology Centre (CTC), Royal North Shore Hospital, North Sydney, Australia. 